\title{
Surface Water Quality-Assurance Plan for the Alabama District of the U.S. Geological Survey
}

By T. S. Hedgecock, J.L. Pearman, and V.E. Stricklin

U.S. GEOLOGICAL SURVEY

Open-File Report 02-305

Montgomery, Alabama

2002 
U.S. DEPARTMENT OF THE INTERIOR

GALE A. NORTON, Secretary

\section{U.S. GEOLOGICAL SURVEY}

CHARLES G. GROAT, Director

For additional information, contact:

District Chief

U.S. Geological Survey

2350 Fairlane Drive, Suite 120

Montgomery, AL 36116
Copies of this report can be purchased from:

U.S. Geological Survey

Information Services

Box 25286, Federal Center

Denver, CO 80225 


\section{CONTENTS}

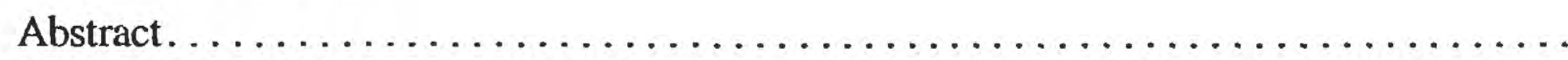

Introduction.

Responsibilities

Collection of stage and streamflow data.

Gage installation and maintenance

Measurement of stage.

Gage documents

Levels

Site documentation

Station descriptions.

Photographs.

Direct measurements.

Field notes.

Acceptable equipment.

Hydroacoustic measurements

Indirect measurements

Crest-stage gages

Artificial controls

Flood conditions

Low-flow conditions.

Cold-weather conditions

Processing and analysis of stage and streamflow data

Measurement and field notes

Continuous record.

Records and computation

Procedures for working and checking records

Gage height

Levels

Rating

Datum corrections, gage-height corrections, and shifts

Hydrographs

Station analysis

Winter records.

Furnished records

Daily values table

Manuscript and annual report

District checkoff list

Review of records

Crest-stage gages

Office setting.

Work plan

File folders for surface-water stations

Field-trip folders 
Level notes

Station descriptions.

Discontinued stations

Map files

Archiving

Communication of new methods and current procedures

Collection of sediment data

Sampling procedures.

Field notes.

Equipment.

Sample handling and storage

High-flow conditions

Cold-weather conditions

Site documentation

Processing and analysis of sediment data

Sediment laboratory

Sediment station analysis

Sediment analysis results

Sediment data storage

Data-base management

Publication of surface-water data

Publication policy

Types of publications

Review process

Streamflow data on the Internet

Safety

Training.

Summary

References

Appendixes

Appendix 1. Water Resources Division and Office of Surface-Water

memorandums cited

Appendix 2. District forms cited. 


\section{Acronyms and abbreviations:}

ADAPS Automative Data Processing System

ADCP Acoustic Doppler Current Profiler

CAP Culvert-analysis program

CSG Crest-stage gages

DCP Data collecton platform

EDI Equal Discharge Increment

EDL Electronic data logger

EWI Equal Width Increment

FRC Federal Records Center

GPS Global Positioning System

HWM High-water mark

MEWI Multiple Equal Width Increment

NWIS National Water Information System

OSW Office of Surface Water

OWQ Office of Water Quality

PZF Point-of-zero-flow

QA Quality Assurance

QA Plan District Surface Water Quality-Assurance Plan

SAC Slope-area computation

SEWI Single Equal Increment

TWRI Techniques of Water-Resources Investigations

USGS U.S. Geological Survey

UWI Unequal Width Increment

WRD Water-Resources Division

WSC Water Survey of Canada

WSPRO Water-Surface Profile Computation model

The use of firm, trade, and brand names in this report is for identification purposes only and does not constitute endorsement by the U.S. Geological Survey. 


\title{
Surface Water Quality-Assurance Plan for the Alabama District of the U.S. Geological Survey
}

\author{
By T.S. Hedgecock, J.L. Pearman, and V.E. Stricklin
}

\section{ABSTRACT}

The U.S. Geological Survey, Water Resources Division, has a policy that requires each District office to prepare a Surface Water Quality-Assurance Plan. The plan for each District describes the policies and procedures that ensure high quality in the collection, processing, analysis, computer storage, and publication of surface-water data. The Alabama District Surface Water QualityAssurance Plan documents the standards, policies, and procedures used by the District for activities related to the collection, processing, storage, analysis, and publication of surface-water data.

\section{INTRODUCTION}

The U.S. Geological Survey (USGS) was established by act of Congress on March 3, 1879, to provide a permanent Federal agency to perform the systematic and scientific "classification of the public lands, and examination of the geologic structure, mineral resources, and products of the national domain." Surface-water activities in the Alabama District are part of the Water Resources Division's (WRD) overall mission of appraising the Nation's water resources. Surface-water information, including streamflow, stage, and sediment data, are used at the Federal, State, and local levels for resources planning and management.

This District Surface Water QualityAssurance Plan (QA Plan) documents the standards, policies, responsibilities, and procedures used by the Alabama District for activities related to the collection, processing, storage, analysis, and publication of surface-water data. The Alabama
District conducts surface-water data-collection activities through offices in Montgomery and Tuscaloosa. Operations in each office are supervised by the Senior Surface-Water Technician (Senior Technician) in that office under the supervision of the District Data-Section Chief.

This QA Plan identifies individual responsibilities for ensuring that stated national policies and procedures are followed. The plan also serves as a guide for all District personnel involved in surface-water activities and as a resource for identifying memorandums, publications, and other literature that describe associated techniques and requirements in more detail.

The scope of this report includes discussions of the policies and procedures followed by this District for the collection, processing, analysis, storage, and publication of surface-water data. Specific types of surface-water data include stage, streamflow, sediment, and basin characteristics. In addition, issues are presented that relate to management of the computer data base and employee safety and training. Although procedures and products of interpretive projects are subject to the criteria presented in this report, specific interpretive projects are required to have a separate and complete quality-assurance plan. This QA Plan is reviewed and revised at least once every 3 years to keep responsibilities and methodologies current; and to ensure that ongoing procedural improvements can be effectively documented.

\section{RESPONSIBILITIES}

Quality assurance (QA) is an active process. Achieving and maintaining highquality standards for surface-water data are accomplished by specific actions carried out by specific persons. Errors and deficiencies can result when individuals fail to carry out their responsibilities. Clear and specific 
statements of responsibilities promote an understanding of each person's duties in the overall process of assuring surface-water data quality. The responsibility for implementation of the QA Plan is spread throughout the District. Much of the responsibility rests with the Hydrologic Data Section, however, ultimately quality assurance is the responsibility of the District Chief. The following list summarizes responsibilities of District personnel involved in the collection, processing, storage, analysis, or publication of surface-water data.

District personnel in the positions mentioned in the subsequent paragraphs can change frequently. As of the publication of this report, they are

District Chief, Athena Clark;

Data-Section Chief, Leroy Pearman;

Tuscaloosa Data Unit Chief, Vic Stricklin;

Surface-Water Specialist, Scott Hedgecock;

Senior Surface-Water Technicians, Doug Batemon, Bill Hard, and Danny Berlin;

District Safety Officer, Richard Moreland.

\section{Responsibilities of the District Chief}

1. Managing and directing the District program, including all surface-water activities.

2. Ensuring that surface-water activities in the District meet the needs of the Federal Government, the Alabama District, State and local agencies, other cooperating agencies, and the general public.

3. Ensuring that all aspects of this QA Plan are understood and followed by District personnel. This is accomplished by the District Chief's direct involvement or through clearly stated delegation of this responsibility to other personnel in the District.

4. Providing final resolution of any conflicts or disputes related to surface-water activities. within the District.

5. Briefing subordinates on procedural and technical communications from Regional Offices and Headquarters.
6. Ensuring that all publications and other technical communications released by the District are accurate and are in accordance with USGS policy.

\section{Responsibilities of the Data-Section Chief}

1. Ensuring that the section personnel receive the proper training in all aspects of field and office procedures.

2. Assisting the District Chief in preparing annual cost for operation and maintenance costs for the sound financial operation of the Hydrologic Data Section.

3. Ensuring remedial actions are taken to correct any observed or suspected program or project deficiency.

4. Sharing duties and other responsibilities with the Surface-Water Specialist to ensure the quality of surface-water data for the District.

5. Assigning experienced field and office personnel for on-the-job training of new employees in standard, acceptable field practices

6. Ensuring that field and office activities are performed in accordance with specified WRD standard practices and policies.

7. Ensuring that field and office activities are performed by adequately qualified, experienced, and supervised personnel.

8. Ensuring that all surface-water activities and procedures receive appropriate and timely review for completeness, reliability, credibility, and conformance to specified standards.

9. Examining data collected by inexperienced field personnel for completeness, accuracy and adherence to prescribed collection techniques

\section{Responsibilities of the Surface-Water Specialist}

1. Assuring that proper methods are used for collecting all types of surface-water data in the Alabama District.

2. Serving as the District Flood Specialist for documenting flood events and is assisted by designated personnel from the Hydrologic Data Section or other sections, as needed. 
2. Performing checks of individual personnel for proper field and data-collection proceduresfrequency of these checks are based on the experience and complexity of work being done. Even the most experienced personnel are checked at least on a biennial basis.

4. Assuring that District surface-water programs and projects are planned to efficiently and effectively provide information required to solve high priority areal or national water problems and to satisfy local needs.

5. Sharing duties and other responsibilities with the Data-Section Chief to ensure the quality of surface-water data for the District.

6. Assisting in or conducting appropriate technical training for District personnel.

7. Performing spot checks on individual field practices-the frequency and intensity of these checks are generally matched with each field person's individual capabilities and experience.

\section{Responsibilities of the Senior Surface- Water Technicians}

1. Examining data collected by field personnel for completeness, accuracy and adherence to prescribed collection techniques.

2. Performing intensive examinations of employee's data collection and field procedures to ensure that the employee possesses a thorough knowledge of technical concepts and demonstrates acceptable practical skills.

3. Planning, organization, and coordination of all routine field trips for personnel in their respective offices who are in the Hydrologic Data Section.

\section{Responsibilities of the Safety Officer}

1. Inspecting field installations annually. The District Safety Officer, ensures adherence to Division and local safety standards and proper operation and maintenance of data-collection facilities. Deficiencies are documented and transmitted to the appropriate supervisory personnel for immediate resolution.

2. Preparation and implementation of a District Safety Plan.
Overall responsibilities of personnel in Surface-Water Data Section:

Ensuring the highest level of accuracy of all streamflow data collected by following prescribed procedures and guidelines set forth by Office of Surface-Water (OSW) and Alabama District.

\section{COLLECTION OF STAGE AND STREAMFLOW DATA}

Many of society's daily activities, including industry, agriculture, energy production, waste disposal, and recreation, are closely linked to streamflow and water availability; therefore, reliable surface-water data are necessary for planning and resource management. The collection of streamflow data is a primary component in the ongoing operation of streamflow-gaging stations (referred to in the remainder of this report as gaging stations) and other water-resource studies performed by the USGS and the Alabama District.

The objective of operating a gaging station is to obtain a continuous record of stage and discharge at the site (Carter and Davidian, 1968, p. 1). A continuous record of stage is obtained by installing instruments that sense and record watersurface elevation in the stream. Discharge measurements are made at periodic intervals to define or verify the stage-discharge relation and to define the time and magnitude of variations in that relation.

It is the policy of the Alabama District that all personnel involved in the data-collection activities are in conformance of the WRD guidelines pertaining to the collection of stage and streamflow data. All employees are informed of and follow the surface-water data-collection policies and procedures established by WRD.

\section{Gage Installation and Maintenance}

Proper installation and maintenance of gaging stations are critical activities for ensuring quality in streamflow-data collection and analysis. Effective site selection, correct design and construction, and regular maintenance of a gage can make the difference between efficient and accurate determination of drainage-basin discharge or timeconsuming, poor estimations of flow. 
Sites for installation of gaging stations are selected with the intent to meet the purpose of each specific gage. Additionally, sites are selected with the intent of achieving, to the greatest extent possible, ideal hydraulic conditions. Criteria that describe the ideal gaging-station site are listed in Rantz and others (1982, p. 5). These criteria include, unchanging natural controls that promote a stable stage-discharge relation, a satisfactory reach for measuring discharge throughout the range of stage, and the means for efficient access to the gage and measuring location. Other aspects of controls considered by District personnel when planning gage-house installations include those discussed in Kennedy (1984, p. 2). Another important selection consideration is that of a safe bridge and measuring section. Some sites may be deemed unsuitable due to safety considerations.

The individuals responsible for selecting sites for new gaging stations are the Data-Section Chief, Surface-Water Specialist, or the Senior Technician. The process of site selection includes discussion with cooperators on the purpose of the gage, analysis of terrain with the use of topographic maps, field reconnaissance, evaluation of types of installation and equipment options, and a file search to determine if discontinued stations or partial record stations existed in the area. The responsibility for ensuring proper documentation of agreements with property owners is held by the Data-Section Chief or Senior Technician. Approval of site design, construction of gages, and inspection and approval of the completed installation is the responsibility of the Data-Section Chief or Senior Technician.

A program of careful inspection and maintenance of gages and gage houses promotes the collection of reliable and accurate data. Allowing the equipment and structures to fall into disrepair can result in unreliable data and safety problems. It is Alabama District policy that a visual inspection is performed at sites by field personnel during each site visit, if possible. To prevent the buildup of mud or the clogging of intakes, stilling wells are pumped and intakes are flushed as needed or at least annually at streamflow-gaging stations; and gages that are equipped with intakes and flushing devices are flushed during each site visit. Other maintenance activities performed on a regular basis include running levels, calibration of equipment, checking battery voltage, and other measures, as needed.

It is the responsibility of each field person, Data-Section Chief, or Senior Technician to ensure that gages and gage houses are kept in good repair. To ensure these responsibilities are carried out, annual inspection forms are filled out by the servicing hydrologist or technician for each gage. Inspections include but are not limited to physical structure, outside gages, inside gages, cableway, equipment, and measuring section(s). Approximately 10 percent of the gages are checked by the Data-Section Chief, Tuscaloosa Data-Unit Chief, or Safety Officer each year on a random basis. Any deficiencies are communicated to the persons responsible for the gaging stations and actions are taken by these persons to immediately correct the deficiencies.

\section{Measurement of Stage}

Many types of instruments are available and are always improving to measure the water level or stage at gaging stations. There are nonrecording gages (Rantz and others, 1982, p. 24) and recording gages (Rantz and others, 1982, p. 32). Because the uses to which stage data may be used cannot be predicted, it is Office of Surface Water (OSW) policy that surface-water stage records be collected at stream sites having instrumentation and procedures to provide sufficient accuracy supporting computation of discharge from a stagedischarge relation, unless greater accuracy is required (OSW memorandum 93.07).

In general, operation of gaging stations for the purpose of determining daily discharge includes the goal of collecting stage data at the accuracy of \pm 0.01 foot for stages less than 15 feet and \pm 0.1 foot for stages greater than 15 feet (OSW memorandum 89.08). In cases where lower accuracy is acceptable the project proposal or station descriptions and analyses will state why a lower accuracy is being used. An explanation of WRD policy on stage-measurement accuracy as it relates to instrumentation is provided in OSW memorandum 96.05. This memorandum gives new accuracy limitations to be $\pm \mathbf{0 . 0 1}$ foot for stages less than 15 feet and $\pm 0.1 \%$ for stages greater than 
15 feet. This means that the accuracy is 0.02 foot for 20 feet, $\mathbf{0 . 0 3}$ foot for $\mathbf{3 0}$ feet and so on.

The types of instrumentation installed at any specific gage house operated by the Alabama District is dependent on physical site conditions for choosing appropriate instrumentation needs as well as the needs of the cooperator, the availability of utility lines for land-line data access, types of terrain, expected range of stage, and other factors that would influence the data-collection process. Types of water-level recorders operated by personnel in this District include various types of analog, electronic-digital (EDL), data collection platforms (DCP), submersible pressure sensors, non-submersible transducers; and will include other types of instrumentation as they are developed and tested.

The responsibility for determining the type of water-level recorders and at what data collection increment they are operated for each gaging station is held by the Data-Section Chief, Senior Technician, or Tuscaloosa Data Unit Chief. Ensuring that new equipment has been installed correctly is the responsibility of the Data-Section Chief, Senior Technician, Tuscaloosa Data Unit Chief, or Surface-Water Specialist. Proper maintenance of gage instrumentation or replacement, if appropriate, of equipment is the responsibility of the field personnel who service the gage.

Accurate stage measurement requires not only accurate instrumentation but also proper installation and continual monitoring of all system components to ensure the accuracy does not deteriorate with time (OSW memorandum 93.07). To ensure that instruments, located within the gage house, record water levels that accurately represent the water levels of the body of water being investigated, "inside" and "outside" water-level readings are obtained by independent means and are compared to the designated reference gage, as described in the station description and station analysis. The inside gage readings do not necessarily always equal outside readings, especially if the gages are not in the same pool at all ranges of stage. At stations equipped with a stilling well, the base or reference gage usually is an instrument installed inside the gage house, and other gages are installed outside the gage house to indicate whether or not the intakes are operating properly (Rantz and others, 1982, p. 53 and p. 64).

Personnel servicing the gage are responsible for comparing inside and outside gage readings during each site visit to determine if the outside water level is being represented correctly by the gages. If a deficiency is identified, the personnel servicing the gages are responsible for thoroughly documenting the problem on the field note sheet and either correcting the problem immediately or contacting the Data-Section Chief, Senior Technician, Tuscaloosa Data Unit Chief, or Surface-Water Specialist so that corrective actions can be taken at the earliest opportunity.

Ensuring that instrumentation installed at gaging stations is properly serviced and calibrated is the responsibility of the Data-Section Chief, Senior Technician, Tuscaloosa Data Unit Chief, or Surface-Water Specialist. This responsibility is accomplished by spot checking data from several gages using real-time data or periods immediately following field trips. When deficiencies are identified, field personnel are instructed by the Data-Section Chief, Senior Technician, Tuscaloosa Data Unit Chief, or Surface-Water Specialist to replace equipment, or are provided further instruction for proper calibration procedures, or other options that are appropriate. Individuals who have questions related to the calibration and maintenance of water-level recorders should contact the Data-Section Chief, Senior Technician, Tuscaloosa Data Unit Chief, or Surface-Water Specialist. The standard procedures for documenting corrections to gage height data are covered in OSW memorandum 91.09.

Most of the basic concepts and procedures used in surface-water data collection activities are presented in the three "Techniques of WaterResources Investigations of the U.S. Geological Survey" (TWRI) series chapters entitled "General Procedures for Gaging Streams," "Stage Measurements at Gaging Stations," and "Discharge Measurements at Gaging Stations." A number of the important aspects contained in these references are enumerated and reinforced here. Generally, all surface-water data collection activities are in accordance with procedures as outlined in the TWRI's. For data collection activities not adequately covered by written instruction, 
supervisors only assign personnel who are capable through unique experience or special training.

On-the-job training of new employees in standard, acceptable field practices is performed by designees of the Data-Section Chief. In all cases, instructors are experienced and knowledgeable concerning prescribed techniques and proper procedures. Data collected by inexperienced field personnel are closely examined for completeness, accuracy and adherence to prescribed collection techniques by the appropriate field office or District Office Senior-Technician and designated members of the Hydrologic Data Unit. The intensity of the examinations remains at a high level until such time as the employee possesses a thorough knowledge of technical concepts and demonstrates acceptable practical skills.

To ensure that personnel are knowledgeable concerning currently prescribed practices, procedures, and methodologies, and that existing guidelines are followed, the District Training Officer and Discipline Specialist in cooperation with appropriate section chiefs, project leaders and individuals, identify training needs and conduct, direct, or arrange formal technical training sessions. Formal training needs are addressed in each individual's training plan. These plans are updated at least once a year along with other aspects of individual career development plans. Updates are made as required by training received, reassignment, or project activities changes.

\section{Gage Documents}

It is District policy that certain documents are placed in each gage house for the purpose of keeping an on-site record of observations, equipment maintenance, structural maintenance, and other information helpful to field personnel. Documents maintained at each gage house include (1) the most recent digital stage-discharge relation (rating); (2) a graph of the rating upon which each new measurement is plotted; (3) the most recent station description listing all gages and reference marks at the site and associated elevations, locations of measurement cross sections, information related to extreme events including the potential for channel storage between the gage and measuring section during flood conditions, and other information (see the section "Site
Documentation, Station Description" in this report); (4) a log updated by field personnel upon each site visit describing control conditions and listing gage readings, measurement values, gagehouse maintenance, and equipment maintenance; (5) a calendar; (6) important telephone numbers.

It is the responsibility of the Data-Section Chief, Senior Technician, Tuscaloosa Data Unit Chief, and field personnel who run a field trip regularly to exchange outdated material with updated gage documents as needed. Individuals having questions related to what documents should be kept in a gage house, when the documents should be replaced with newer documents, or appropriate methods of appending logs or plotting measurements should contact the Data-Section Chief or Senior Technician.

\section{Levels}

The various gages at a gaging station are set to register the altitude of a water surface above a selected level reference surface called the gage datum. The gage supporting structures (such as, stilling wells, backings, shelters, bridges, and other type structures) tend to settle or rise as a result of earth movement, static or dynamic loads, vibration, or battering by floodwaters and flood-borne debris. Vertical movement of a structure makes the attached gages read too high or too low and, if the errors go undetected, may lead to increased uncertainties in streamflow records. Leveling, a procedure by which surveying instruments are used to determine the differences in altitude between points, is used to set the gages and to check them from time to time for vertical movement (Kennedy, 1990 , p. 1). Levels are run periodically to all bench marks, reference marks, reference points, and gages at each station for the purpose of determining if any datum changes have occurred (Rantz and others, 1982, p. 545).

It is District policy that levels are run at newly installed gaging stations either at the time of construction or within 6 weeks of when record collection begins. Levels are run to established gaging stations once every 5 years or more often as conditions warrant as covered by TWRI, Book 3, Chapter A19, "Levels at Streamflow Gaging Stations," Kennedy (1990, p. 14), and OSW memorandum 90.10. Gages are reset to agree with 
levels when the levels indicate at least a 0.02 -foot vertical change. Level notes are checked before the reset is made. When gages are reset, field personnel document the reset by including pertinent information on level field notes and miscellaneous note sheets. Standard field note forms indicate the information requirements for routine operational activities such as current-meter discharge measurements and stream-gage recorder servicing. However, supplemental notes are required for reporting unusual conditions, deviations from standard practice, personal judgments, and all other information that may be of subsequent value.

Field notes identify the procedures, specifications, and regulations followed; describe the unmeasured variables that can affect the accuracy and reliability of determinations; indicate any uncertainties or deviations from common practice; and report information that could affect the analyses, interpretation or use of the data. For less structured field activities, such as indirect discharge measurements or gage datum checks, available forms provide only recording space and special effort is required to assure that notes are appropriate, complete, and accurate.

All field measurements and observation notes are recorded in an acceptable format as a permanent record. Field notes are neat, readable, and leave no doubt about interpretation. All information is recorded as it is collected and never documented from memory.

Levels are run by use of field methods and documentation methods described in Kennedy (1990) and in TWRI, Book 3, Chapter Al9. Level procedures followed by District personnel pertaining to circuit closure, instrument reset, and repeated use of turning points are described in Kennedy (1990), in OSW memorandum 93.12, and in TWRI, Book 3, Chapter A19. The level instruments are kept in proper adjustment by proper care and handling of equipment. Annual peg tests are performed and documented, and any corrections made are noted on the peg-test form. A log of peg tests for each instrument is kept in each field office and a copy of the latest peg test is kept with the instrument.
It is the responsibility of the field person, Senior Technician, Tuscaloosa Data Unit Chief, or Data-Section Chief to ensure that field level notes are checked. The level information is entered in the level-summary form by field personnel involved in running the levels and are checked during the station analysis procedures for the year. Ensuring that levels are run correctly and that all level notes are completed correctly is the responsibility of the field person, Senior Technician, Tuscaloosa Data Unit Chief, or Data-Section Chief. Ensuring that levels are run at the appropriate frequency is the responsibility of the field person, Senior Technician, Tuscaloosa Data Unit Chief, or DataSection Chief.

\section{Site Documentation}

Thorough documentation of qualitative and quantitative information describing each gaging station is required. This documentation, in the form of a station description and photographs, provides a permanent record of site characteristics, structures, equipment, instrumentation, altitudes, location, and changes in conditions at each site. Information pertaining to where these forms of documentation are maintained is discussed in the section of this report entitled "Office Setting."

\section{Station Descriptions}

A station description is prepared for each gaging station and becomes part of the permanent record for each station. It is District policy that the station description is written by the time the first year's records are computed and analyzed. The responsibility for ensuring that station descriptions are prepared correctly and in a timely manner is held by the field person, Senior Technician, Tuscaloosa Data Unit Chief, or Data-Section Chief. It is the responsibility of the field person, Senior Technician, Tuscaloosa Data Unit Chief or DataSection Chief to ensure that station descriptions are updated. Station descriptions are reviewed each year during the annual station analysis report process and are updated as needed. Station descriptions are written to include specific types of information in a consistent format (Kennedy, 1983, p. 2, fig.1 and 2). 


\section{Photographs}

Photographs of newly installed gage houses, station controls, reference marks, damaged structures, and other pertinent information are made by field personnel for the purpose of documenting gage-house construction, changes in control conditions, or to supplement various forms of written descriptions. It is not regular practice for all field personnel to carry cameras, but cameras are available at anytime from the Senior Technician or Data-Section Chief. Each photograph that becomes part of the station record is identified with gage information on the back of the photograph with a permanent-ink marker. Photographs also are taken for indirect measurements; stereo photographs and aerial photographs to document surface-water gagingstation structures, channels or controls for major events. Photographs for the gage are placed in the historical files or with indirect measurements for each station.

\section{Direct Measurements}

Direct measurements of discharge are made with any one of a number of methods approved by WRD. The most common is the current-meter method.

A current-meter measurement is the summation of the products of the subsection areas of the stream cross section and their respective average velocities (Rantz and others, 1982, p. 80). Procedures used for current-meter measurements are described in Rantz and others (1982, p. 139), Carter and Davidian (1968, p. 7), and Buchanan and Somers $(1969$, p.).

When personnel make measurements of stream discharge, attempts are made to minimize errors. Sources of errors are identified in Sauer and Meyer (1992). These include random errors such as depth errors associated with soft, uneven, or mobile streambeds; or uncertainties in mean velocity associated with vertical-velocity distribution errors and pulsation errors. These errors also include systematic errors or bias associated with improperly calibrated equipment or the improper use of such equipment. In order to minimize systematic errors, field trips are rotated to different personnel every year.
District policies related to the measurement of discharge by use of the current-meter method, in accordance with WRD policies, include the following. Current meter discharge measurements are computed in the field and checked against the current rating curve. If the measurement exceeds normal tolerance or differs substantially from recent trends in measured discharge, a check measurement is made, computed and also checked against the rating curve. Normal tolerance is generally 5 percent. However, many streams in Alabama have loose sand channel controls and are subject to considerable shifting. Normal tolerance for these streams is within 10 percent. During extreme low water conditions, the measurement is compared to the more recent measurements in regard to rating shape. In order to ensure and document the accurate performance of meters used to make streamflow discharge measurements, the District uses care and maintenance procedures and spin-test documentation as recommended by OSW Technical Memorandums 89.07 and 99.06 . Individual responsibilities are well documented by the memorandum and all persons who make current meter streamflow measurements are expected to follow the procedures as outlined. The prescribed spin-test logs are maintained in each office.

Depth criteria for meter selection.--District personnel select the type of current meter to be used for each discharge measurement on the basis of criteria provided by the OSW (written commun., 1995), Meters are used with caution when a measurement must be made in conditions outside of the ranges of the method provided by OSW. Any deviation from those criteria are noted and the measurement accuracy is downgraded accordingly.

Number of measurement subsections.--The spacing of observation verticals in the measurement section can affect the accuracy of the measurement (Rantz and others, 1982, p. 179). The Alabama District criteria are that observations of depth and velocity be made at a minimum of about 25-30 verticals, which are normally necessary so that no more than 5 percent of the total flow is measured in any one vertical. Even under the worst conditions, the discharge computed for each vertical should not exceed 10 percent of the total discharge and ideally not exceed more than 5 
percent (Rantz and others, 1982, p. 140). Exceptions to this policy are allowed in circumstances where accuracy would be sacrificed if this number of verticals were maintained, such as for measurements during rapidly changing stage (Rantz and others, 1982, p. 174). Fewer verticals than are ideal are sometimes used for very narrow streams. Measurement of discharge is essentially a sampling process, and the accuracy of sampling results typically decreases markedly when the number of verticals are less than 25 .

Other direct methods of measuring discharge. -It is District policy that WRD and OSW techniques and guidelines are followed when discharge measurements are made with any selected method. These methods include using the Acoustic Doppler Current Profiler (ADCP). The ADCP methods used are in accordance with USGS standard procedures and are documented as described by (Lipscomb, 1995). Volumetric techniques and methods involving portable weirs and flumes are used occasionally, and are made in accordance with prescribed procedures as covered by Rantz and others (1982), Buchanan and Somers (1969), and Kilpatrick and Schneider (1983).

Computation of mean gage height.--District personnel use procedures for the computation of mean gage height during a discharge measurement presented in Rantz and others (1982, p. 170). Mean gage height is one of the coordinates used in describing the stage-discharge relation at a streamflow-gaging site.

Check measurements.-- A second discharge measurement is often made for the purpose of checking a first discharge measurement. If the measurement exceeds normal tolerance, a check measurement is made, computed and also checked against the rating curve. Normal tolerance is generally within 5 percent. However, many streams in Alabama have loose sand channel controls and are subject to considerable shifting. Normal tolerance for these streams is within 8 percent. Exempt from the check measurement policy are measurements made on highly regulated streams where the previous measurement conditions no longer exist, are changing rapidly, or are expected to change immediately due to regulation patterns. Also exempt from the check measurement policy are measurements made where somewhat permanent changes in the control are observed, such as beaver dams and movement of rocks in channel during low flow conditions and those which are in alignment with recent measurements and are defining a new rating curve.

Corrections for storage.--Corrections for storage applied to measured discharges for the purpose of defining stage-discharge relations are those discussed in Rantz and others, 1982, p. 177 and in OSW memorandum 92.09.

Questions.--Personnel who have questions concerning the appropriate procedures for making stage and discharge measurements should address their questions to the Data-Section Chief, Tuscaloosa Data Unit Chief, Senior Technician, or Surface-Water Specialist.

\section{Field Notes}

Thorough documentation of field observations and data-collection activities performed by field personnel are a necessary component of surfacewater data collection and analysis. To ensure that clear, thorough, and systematic notations are made during field observations, discharge measurements are recorded by field personnel on standard measurement forms. Original observations, once written on the note sheet, are not erased. Original data are corrected by crossing the value out then writing the correct value. Examples of information on a discharge-measurement note sheet that is derived from original data, but not in itself original data, include the total discharge on the front sheet and mean gage height. Derived data can be erased for the purpose of correction.

It is District policy that all discharge measurements are calculated in their entirety before field personnel leaves the field site, unless emergency evacuation is required for reasons of safety. Information required to be included by field personnel on the measurement note sheet includes, at minimum, the initials and last name of all fieldparty members, station name, station number, date, times associated with gage readings, and other pertinent observations.

Notations associated with miscellaneous surface-water data-collection activities are to be documented on miscellaneous notes. All 
miscellaneous notes are required to include, at minimum, initials and last name of field-party members, station name, station number, date, time associated with observations and purpose of the site visit.

A review of field note sheets is required annually as part of surface-water records review by field personnel, Senior Technician, Data-Section Chief, or Surface-Water Specialist. Deficiencies found in the content, accuracy, clarity, or thoroughness of field notes are identified and communicated to appropriate field personnel by written or oral means by the Senior Technician, Data-Section Chief, Tuscaloosa Data Unit Chief, or Surface-Water Specialist. The deficiencies are remedied by providing specific instructions to individuals who fail to record notations that meet USGS and District standards.

\section{Acceptable Equipment}

Equipment used by the Alabama District for the measurement of surface-water discharge has been found acceptable by the WRD through use and testing. An array of acceptable equipment for measuring discharge includes current meters, timers, wading rods, bridge cranes and tag lines (Rantz and others, 1982, p. 82; Smoot and Novak, 1968). Although an official list of acceptable equipment is not available, Buchanan and Somers (1969), Carter and Davidian (1968), and Edwards and Glysson (1988) discuss the equipment used by the U.S. Geological Survey.

The meters most commonly used by District personnel for measuring surface-water discharge are the Price AA current meter and the Price pygmy current meter. Methods followed by District personnel for inspecting, repairing, and cleaning these meters are described in Smoot and Novak (1968, p. 9), Rantz and others (1982, p. 93), and Buchanan and Somers (1969, p. 7).

The ultimate responsibility for the good condition and accuracy of a current meter rests with field personnel who use the equipment (OSW memorandums 89.07 and 99.06). A timed-spin test made a few minutes before a measurement does not ensure that the meter will not become damaged or fouled during the measurement. Field personnel must assess apparent changes in velocity or visually inspect the meter periodically during the measurement to ensure that the meter continues to remain in proper operating condition.

Office spin tests.--It is District policy that office spin tests are required prior to each field trip or at least once a quarter. Spin-test results are documented in a $\log$ that is maintained for each instrument, and lists all spin tests for all current meters in chronological order. The log is located in each field office. This log is part of the archived data of WRD (OSW memorandum 89.07). Repairs are made to meters when deficiencies are identified through the spin test or inspection. Review of this $\log$ by the Senior Technician is required at least annually. If deficiencies are observed during this review of the $\log$, the field person is informed through oral or written communication and the problem is corrected immediately. An overall review of the log is performed by the Data-Section Chief, Tuscaloosa Data Unit Chief, or SurfaceWater Specialist during annual program review and any deficiencies are promptly corrected by field personnel.

In addition to the timed-office spin tests, field personnel are required to perform a field spin test and inspect the meter before and after each measurement to ensure that the meter is in good condition, that the cups spin freely, and the cups do not come to an abrupt stop. Descriptive notations are made at the appropriate location on the fieldnote sheet concerning the meter condition, such as "OK" or "free" or other such comments. To ensure that field personnel carry out their responsibilities to maintain the equipment they use, the equipment is inspected by the Senior Technician, DataSection Chief, Tuscaloosa Data Unit Chief, or Surface-Water Specialist during annual review, and any deficiencies are promptly corrected by field personnel.

\section{Hydroacoustic Measurements}

The Acoustic Doppler Current Profiler is used to measure discharge in rivers or estuaries and has expanded the hydrologic conditions that can be measured. Instead of measuring just point velocities, it measures velocities throughout the water column and the cross section. Also, it measures discharge much faster than a conventional measurement. Sites that were difficult to measure before are usually safer and easier to 
measure with an ADCP. The instrument can be deployed in a manned boat or an unmanned platform.

\section{Training}

Due to the complexity of the principles of operation, the ADCP instrument, and the software, personnel must have taken the OSW training class Measurements of Streamflow using ADCPs to collect and review hydroacoustic discharge measurements. Before taking this class, the student should make at least one measurement in the field with an experienced user and complete the required preclass assignments. The experienced user has the responsibility of giving a rudimentary explanation of how the hydroacoustic instrument gathers data, what is measured and not measured, the limitations of the instrument, and how the software works.

Since acoustic instruments and their related software continually change and improve, experienced users must keep abreast of the current OSW policies and procedures by subscribing to the acoustics mailing list, reviewing the OSW ADCP Web pages, and attending a USGS refresher class or workshop. The Hydroacoustic Work Group provides operational guidance for acoustic instruments and their ancillary equipment through the web pages, the mailing list, or direct contact with experienced people. Experienced and unexperienced users should not hesitate to call for help when problems arise because the complexity of the system is great. For guidance on using Global Positioning System (GPS) equipment and fathometers with the hydroacoustic instrument and other advanced applications, OSW offers a training course entitled, Advanced ADCP Applications.

\section{Pre-Field Operation}

Before taking the instrument into the field, the user should inspect the instrument, laptop (data logger), and communication cable (or modems) to ensure that they are operational, and any batteries to be used must have the required voltage. The inspection should include checking for physical damage, making sure that the acoustic instrument communicates with the laptop at an acceptable baud rate, and the date and time on the instrument and laptop are correct. To make sure that the internal electronics are acceptable, execute an electronics test program, such as $A D C P$ test for the RD Instruments $A D C P$, with the instrument in water.

The tools and spare parts for the instrument (fuses, o-rings) should be included as well a digital or hard copy of the instrument technical manual. Also, the hardware to mount the instrument to the boat should be inspected to ensure that it is acceptable (stable enough to remain rigid in the expected water velocities) and that the instrument is not mounted near any ferrous materials on the boat. Any additional equipment should be checked for proper operation.

\section{Field Operation}

A digital copy of the test log should be created before measurements are made once the instrument is in the water. This can be done by using, for example, the $A D C P$ test for the $\mathrm{RD}$ Instruments ADCP. This script will ask for a filename and directory to store the test file. The directory is $C:$ adcpldatavest, and the test file can be named after the site name and date. An example of the test filename for a measurement on the Alabama River on May 14,2002, is alariver.0514.02. This file will have the serial number, frequency, and firmware of the instrument as well as the test data. Review this file to verify that the instrument passes the tests. If the instrument fails the test, see the Troubleshooting Guide in the Technical Manual of the instrument.

To store the measurement data in the data logger, the directory structure is adcpldata under the root directory. A folder for the site to be measured should exist or be created here. The folder name is derived from the site name. The path to this location should be set in the Recording section of the configuration file, and the file name prefix should use the station number and possibly water mode if the water mode might change for different conditions. For example, data for Cahaba River near Suttle are stored with filename prefixes of $\mathrm{s} 02424590_{\text {_ }}$ and are stored in the directory $C$ : Vadcpldatalsuttle. For the RD Instruments $\mathrm{ADCP}$, the measurement data are stored in a file appended with the transect number and an $r$ or $w$ where $r$ refers to the raw data file (or the measurement) and the $w$ is the configuration file for that transect. For example, the first transect for 
station 02420000 will create a raw data file called s02420000_000r.000 and its associated configuration file called $s 02420000 \_000 w .000$. The next transect will be $502420000 \_001 r .000$ with a configuration file of $502420000 \_001 w .000$. A copy of the original configuration file should be saved in the file C: ladcpldatalconfig.

The note sheet No. 9-275-I is very important to the operator when processing the data. Every thing should be recorded on the field note sheet as outlined in OSW Technical Memo 2002.02--Policy and Technical Guidance on Discharge Measurements using Acoustic Doppler Current Profilers and in Simpson (written commun., 2002). All of the blanks should be filled on the sheet since most changes that need to be made can be done during data processing. Some changes can greatly affect the data. Even weather conditions such as wind direction, can help qualify the data or make changes to a discharge estimation method.

A very important component of the discharge measurement procedure is the operation of the boat and is discussed by Simpson (preliminary, 2002). The boat driver should adhere to the Department of Interior rules for boat operation. The person operating the acoustic instrument should explain how the boat should be driven beforehand and have good communication with the boat driver. The boat driver should drive the boat smoothly, with a minimum of sudden turns or velocity changes. The passengers on the boat should remain reasonably still so as to keep the pitch and roll constant. Also, the boat speed should be no faster than the water velocity. In the event of varying flow conditions, the boat speed may need to be greater than the water speed. If the acoustic instrument will be operated by an unmanned platform, boat operation is the same.

When using the hydroacoustic instrument to make a discharge measurement, the best available discharge measurement site should be selected. The guidelines in Water Supply Paper 2175 (Rantz and others 1982) should be followed to choose a site to measure discharge. These guidelines, coupled with the knowledge of the acoustic instrument's capabilities and limitations, can avert many problems.
Once the measuring cross section is selected, a moving bed test must be conducted before measurements are made. The moving bed test is made by holding the boat as stationary as possible for about 5 to 10 minutes while recording flow data; if the ship track plot shows the boat moving upstream, a moving bed is present. When a moving bed is encountered, an attempt to find a more acceptable location should be made. If a site cannot be found that does not have a moving bed, a DGPS capable of sub-meter accuracy, and possibly a fathometer for depth if the moving sediment layer is thick enough, should be used to collect boat location information. The Advanced Applications class provides guidance on the methodology of using a DGPS and fathometer with the hydroacoustic instrument. If these are not available, the measurement should have that noted on the field sheet and be downgraded. The only time that a moving bed test should be skipped is when the site has been checked over numerous visits at the present flow conditions and it has no moving bed.

With the pitch and roll sensors are reading no more than 2 or 3 degrees, measure the distance from the end of the instrument to the water surface. This is aided by marking these distances on the mount before deployment. When reading the depth, the boat and instrument must be in the position, tilt and roll included, that they will be in during the measurement. This may require a mirror to read the depth. The depth of the instrument should be at least 0.3 feet, but deep enough so that it will not come out of the water during the measurement, and positioned so that none of the beams hit the boat or the boats wake. The salinity at the transducer face, if in a saline environment, should be checked. The depth and salinity should be entered into the "Processing" section of the software and onto the notesheet.

To collect data, the hydroacoustic instrument must be configured correctly for the site and conditions, and the correct software must be used. The latest software for RD Instruments ADCP is described in OSW Technical Memo 2002.03-Release of Winriver Software (version 10.03) for Computing Streamflow from Acoustic Profiler Data. This memo discusses the Configuration Wizard and data screening tools in the software. If 
the operator has an idea of the characteristics of the site, such as water depth and velocity, an instrument configuration file can be created fairly quickly by using the guidelines in OSW Technical Memo 2002.01--Configuration of Acoustic Profilers (RD Instruments) for Measurement of Streamflow. If the user is not familiar with the site, a configuration file can be created for reconnaissance of the site and adjustments made to the file before the actual measurement.

During the reconnaissance, starting and stopping points for the transects can be established with a buoy and measured, and the method of estimating the edge discharge can be selected. If the edges are not marked with a buoy, a range finder should be used to measure the edge distances at the time of starting or stopping a transect. These distances should be entered into the software and the notesheet for each transect. The reconnaissance will also help determine the method of extrapolating the top and bottom unmeasured zones and the edge bank shapes for edge estimations.

One measurement is considered to be the average of four transects, two in each direction to reduce directional biases. If one of the transects differs more than 5 percent from the measured discharge, another set of four transects should be made and the average of all eight will be the measured discharge. Under rapidly varying flow conditions, individual transects may be used as individual measurements. The reasoning behind this decision should be noted on the note sheet. Also, a comparison should be made between the transects to check for a directional bias. The measurements should be checked against a rating if available.

\section{Data Processing}

After returning to the office, the data that was collected must be stored onto the Sun because it is backed up. Storing onto the Sun is done in Windows by copying the files to a directory called $a d c p$ and selecting either Mont for the Montgomery office or Tusc Tuscaloosa office. Underneath this directory is the folder for the site to save the data. For example, the data for Cahaba River near Suttle (station 02424590) collected by the Montgomery office will go into the directory called Sun1dalmtgladcp Mont 102424590 . Before copying it into the appropriate folder, make sure that none of the names are exactly the same to prevent overwriting old data. Both the raw data file and its configuration file should be copied. Any test files should be saved into the test folder under Sun1dalmtgladcpMond for the Montgomery office data.

The recorded data must be examined and rated. The note sheet is very helpful in this endeavor so that the correct configuration file, instrument depth, edge distances and shapes, and top and bottom discharge methods can be used to estimate the unmeasured flow. OSW Technical Memo 2002.03 gives guidance on data screening tools such as 3-beam solutions, error and vertical velocity thresholds, and appropriate fish detection algorithms for $\mathrm{RD}$ Instruments Rio Grande. Occasionally, the file needs to be subsectioned to remove questionable data at the start and end of a transect. The note sheet must be filled out completely at this point. The measurements should be entered into the Automative Data Processing System (ADAPS) with a measurement number and a measurement rating qualifier assigned. The notesheet should be filed in the appropriate measurement sheet file.

\section{Equipment Maintenance}

Once the instrument and cable are retrieved, they should be inspected for physical damage and cleaned; a rinse with clean water is usually adequate. A lint free towel can be used if more cleaning is needed. See RD Instruments Technical Manual (2001) for more cleaning and inspection information. Back at the office, the instrument and carrying case should be air dried.

\section{Indirect Measurements}

In many situations, especially during flooding, it is impossible or impractical to measure peak discharges by means of a current meter. There may not be sufficient warning for personnel to reach the site to make a direct measurement, or physical access to the site during the event may not be feasible. Indirect measurements of discharge are directed by the District Flood Specialist assisted by other qualified personnel of the Hydrologic Data Section. It is the Flood Specialist's responsibility to 
see that indirect measurement computations are made according to appropriate TWRI procedures or to recommend alternative procedures when established methods are not possible due to unusual physical conditions. All indirect measurements are reviewed by the District Surface-Water Specialist; and those made by methods that substantially depart from established procedures are also reviewed by the Regional Surface-Water Specialist.

A peak discharge determined by indirect methods is in many situations the best available means of defining the upper portions of the stagedischarge relation at a site. Because extrapolation of a stage-discharge relation or rating beyond twice the measured discharge at a gaging station is undesirable and may be unreliable, discharge measurements made by indirect methods during periods of high flows are important forms of data (Rantz and others, 1982, p. 334).

The District follows data-collection and computation procedures presented in Benson and Dalrymple (1967). That report includes policies and procedures related to site selection, field survey, identification of high-water marks, selection of roughness coefficients, computations, and the written summary. The District also follows procedures for measurement of peak discharge by indirect methods presented in Rantz and others (1982, p. 273).

In addition to the general procedures presented in Benson and Dalrymple (1967), the District follows guidelines presented in other reports that describe specific types of indirect measurements suited to specific types of flow conditions. The slope-area method is described in Barnes (1967) and Dalrymple and Benson (1967). The USGS applies the Manning equation in application of the slope-area method. Procedures for selecting the roughness coefficient are described in Arcement and Schneider (1989). The computer-based tool, slope-area computation (SAC) program, as described by Fulford (1994), is available to assist in computations of peak discharge with the slope-area method is discussed in OSW memorandum 97.01. Procedures for the determination of peak discharge through culverts, based on a classification system which delineates six types of flow, is described in Bodhaine (1982).
The computer-based tool, culvert-analysis program (CAP), as described in Fulford (1995), is available to assist in computations of peak discharge at culverts, is discussed in OSW memorandums 96.04 and 97.01. At sites where open-channel width contractions occur, such as flow through a bridge structure, peak discharge can be measured with methods described in Matthai (1967) and with the Water-Surface Profile Computation model (WSPRO) (Shearman, 1990). Debris-flow conditions, which are most common in small mountainous basins, are discussed in OSW memorandum 92.11.

Determinations of water-surface profiles along a stream channel in association with selected discharges are made when studies are performed that involve delineations of flood plains or when extensions are made to stage-discharge relations at streamflow sites, when needed. District personnel are required to follow the procedures associated with step-backwater methods described in Davidian (1984). The computer-based tool used for assisting in the computations of water-surface profiles with step-backwater methods, WSPRO, is discussed in OSW memorandum 87.05.

General guidelines that are followed by the District when making indirect measurements include those discussed in OSW memorandum 92.10 and in Shearman (1990). Violation of more than one of the general guidelines does not necessarily invalidate an indirect measurement (OSW memorandum 92.10). The decision to invalidate an indirect measurement is based on the application, knowledge, and experience of the Surface-Water Specialist in reviewing or in computing the measurement.

The responsibility for ensuring that indirect measurements are performed correctly is held by the Surface-Water Specialist. It is required that a review of procedures and documentation be performed on each indirect measurement by the District Surface-Water Specialist or Regional Surface-Water Specialist before finalization of the discharges into any publication or peak-flow files. If deficiencies are found during the review, proposed solutions are communicated by the Surface-Water Specialist to the person that computed the measurement and that person is responsible for ensuring that the corrective actions 
are taken and that the actions actually correct the deficiencies. Measurements that are questionable and difficult to assess are reviewed by specialists outside the District, and the District Surface-Water Specialist is responsible for ensuring that deficiencies identified by the outside party are corrected.

Determining when and where indirect measurements are made is the responsibility of the Surface-Water Specialist, Data-Section Chief, or Tuscaloosa Data Unit Chief. For this District, it is a general rule that indirect measurements are made at sites when the peak flow at a site is estimated to be at least twice the discharge of the greatest measured flow, or it is essential that a peak discharge be determined.

It is the responsibility of trained personnel to identify and flag high-water marks. Because the quality and clarity of high-water marks are best soon after a flood, personnel traveling in the field are required to have available in their field vehicles items such as nails and plastic markers, spray paint, paint sticks, survey flagging, survey stakes, and other items as necessary. Because selection of a suitable reach of channel is an extremely important element in making an indirect measurement, at some streamflow-gaging-station sites, the stream reach for indirect measurements at specified ranges of stage has been preselected and that information has been included in the station description

After each indirect measurement is computed, the graphs, field notes and data, plotted profiles, maps, calculations or computer output, and written analysis associated with the measurement are checked by the Surface-Water Specialist. The information is organized into a folder labeled with all pertinent data and filed in the station or historical indirect measurement files.

The responsibility of maintaining the accuracy of the peak-flow data files, including computer data-base files, lies within the District (OSW memorandum 92.10). It is the responsibility of the Surface-Water Specialist to ensure that appropriate indirect-measurement results are entered into the peak-flow files. It is the responsibility of the Surface-Water Specialist and Data-Section Chief to ensure that the peak-flow files are correct. For further discussion on the update and review of the peak-flow files, refer to the "Data-base Management" section in this QA Plan.

\section{Crest-Stage Gages}

Crest-stage gages (CSG) are used as tools throughout the WRD for determining peak stages at otherwise ungaged sites, confirming peak stages at selected sites where recording gages are located, confirming peak stages where pressure transducers are used, and determining peak stages along selected stream reaches or other locations, such as upstream and downstream from bridges and culverts. The OSW requires quality-assurance procedures comparable to those used at continuous-record stations for the operation of crest-stage gages and for the computation of annual peaks at crest-stage gages (OSW memorandum 88.07).

The operation of crest-stage gages is part of the Alabama District's surface-water program. Procedures followed by this District in the operation of crest-stage gages are presented in Rantz and others (1982, p. 9, 77, 78). One or more gages are maintained at each selected site where peak water-surface elevations are required on a stream. Upstream and downstream gages are maintained at culverts or other structures where water-surface elevations are required to compute flow through the structure and to establish the resulting type of flow.

Except at sites where crest-stage gages are used only to confirm or determine peak stages, stage-discharge relations are developed in association with the gage based on direct or indirect high-water measurements. Direct or indirect measurements are obtained as site conditions warrant to verify or adjust the rating. Levels are run to the gage every 3 years or as soon as possible after significant changes in the gage because of damage, reconstruction, or other such situation. When extremely high peaks occur, an outside high-water mark to confirm the gage reading is found when possible, is described on the note sheet, and is flagged by a durable indicator so that the elevation of the high-water mark (HWM) can be determined the next time levels are run.

Field observations are written on CSG forms or miscellaneous field sheets. All field notes are 
required to include, at minimum, initials and last name of field personnel, station name, station number, date, time of observation, current stage, HWM elevation on stick, and outside HWM, if found.

The responsibility for ensuring that correct data-collection procedures are used by personnel is held by the field persons involved in site visits to gage locations, Senior Technician, Data-Section Chief, Tuscaloosa Data Unit Chief, and SurfaceWater Specialist. Review of data collection procedures and data processing is carried out by each responsible field person and the SurfaceWater Specialist at least once a year as part of the station analysis. When a deficiency in datacollection activities is identified, the problem is remedied by proposed solutions that are communicated by the Surface-Water Specialist to the responsible field person and that person is responsible for ensuring that the corrective actions are taken and that the actions actually correct the deficiencies. A corrected CSG analysis form is kept in folder and reviewed by the Surface-Water Specialist before publication in the Annual Data Report. Policies and procedures for computation of peak discharges ar crest-stage gages and associated documentation are presented in this report in the section entitled, "Processing and Analysis of Stage and Streamflow Data"

\section{Artificial Controls}

Artificial controls, including broad-crested weirs, thin-plate weirs, and flumes, are built in stream channels for the purpose of simplifying the procedure of obtaining accurate records of discharge (Rantz and others, 1982, p. 12). Such structures serve to stabilize and constrict the channel at a section, reducing the variability of the stage-discharge relation.

Artificial controls are used at a few gaging stations maintained by the Alabama District. In situations where artificial controls are installed as permanent structures, it is District policy that stage-discharge relations are determined by making current-meter measurements throughout the range of stage, relying on the design rating when current-meter measurements cannot be made. Portable weir plates and flumes are not currently used by District personnel. These portable device applications, if used, would be in accordance with the methods described in Buchanan and Somers (1969, p. 57) and Rantz and others (1982, p. 263).

Ensuring the correct design and installation of artificial controls for this District is the responsibility of the Data-Section Chief or Surface-Water Specialist. When installing an artificial control, the District personnel take into account the criteria for selecting the various types of controls, principles governing their design, and the attributes considered to be desirable in such structures (Carter and Davidian, 1968, p. 3; Rantz and others, 1982, p. 15 and 348; Kilpatrick and Schneider, 1983, p. 2 and 44).

When field inspections of artificial controls are performed, specific information pertaining to control conditions are written on the field note sheets for the purpose of assisting in analysis of the surface-water data. These notes include comments concerning scour or fill of the streambed immediately upstream from the control, leakage, or other pertinent information that would effect the accuracy of the artificial control structure. When problems pertaining to artificial controls are encountered by field personnel, the Senior Technician, Data-Section Chief, Tuscaloosa Data Unit Chief or Surface-Water Specialist should be contacted in attempting to solve a non-routine problem.

\section{Flood Conditions}

Flood conditions present problems that otherwise do not occur on a regular basis. These problems can include difficulties in gaining access to a streamflow gage or measuring site because roads and bridges are flooded, closed, or destroyed. Debris in the streamflow can damage equipment and present dangers to personnel collecting the data. Rapidly changing stage or conditions requiring measurements to be made at locations some distance away from the gage can create problems in associating a gage height to a measured discharge.

The District maintains a Flood Plan so that high-priority surface-water data associated with flood conditions are collected correctly and in a timely manner. The Flood Plan describes responsibilities before, during, and after a flood, 
informational reporting procedures, and fieldactivity priorities. The Flood Plan serves as a central reference for emergency communications, telephone numbers for key District personnel, and codes for accessing streamflow gages equipped with telemetry.

It is the responsibility of the Data-Section Chief and Surface-Water Specialist to ensure that the Flood Plan includes all appropriate information, including updated information. The Flood Plan is reviewed every 2 years or after a major flood event by the Data-Section Chief and Surface-Water Specialist. A copy of the Flood Plan is provided to each field person. Each individual that receives a copy of the plan keeps copies in their office and in their field truck. It is the responsibility of the Data-Section Chief and Surface-Water Specialist to ensure that individuals that receive a copy of the plan are fully versed on the content of the Flood Plan.

Coordination of flood activities for the District is performed by the District Chief, DataSection Chief, Tuscaloosa Data Unit Chief or Surface-Water Specialist. Communication is the key for effective utilization of the district's resources during a flood. For personnel that are not already in the field, their first responsibility during flood conditions is to come to the office with the intent of going in the field for an extended period of time. Field assignments will be made by the Data-Section Chief or Surface-Water Specialist. For personnel that are already in the field, their first responsibility during flood conditions is to proceed to make measurement at the previously selected streamflow site then call the Data-Section Chief and Surface-Water Specialist via cellular phone/radio or pay phone to report related flood information. Personnel in the field can either utilize cellular phones/radios or pay phones to contact the flood coordinator. Personnel who arrive at a gaging station to find that a flood has already peaked are responsible for calling in information about flood stage and making a discharge measurement; then proceeding to find and document high-water marks. The District personnel apply methods discussed in Rantz and others (1982, p. 60) for determining peak stage at gaging stations.
District personnel follow policies and procedures stated in a number of publications and memorandums when collecting surface-water data during floods. Techniques for current-meter measurements of flood flow are presented in Rantz and others (1982, p. 159 to 170). Procedures for identifying high-water marks for indirect discharge measurements are presented in Benson and Dalrymple (1967, p. 11). Adjustments applied to make measured flow hydraulically comparable with recorded gage height when discharge measurements are made a distance from the gaging station are presented in OSW memorandum 92.09 and in Buchanan and Somers $(1969$, p. 54). It is the responsibility of all personnel with questions about particular policies or procedures related to flood activities, or who recognize their need for further training in any aspect of flood-data collection, to address their questions to the Data-Section Chief or Surface-Water Specialist.

Review of District activities related to floods is the responsibility of the District Chief, DataSection Chief, Tuscaloosa Data Unit Chief, and Surface-Water Specialist. This review includes seeing that guidelines and priorities spelled out in the Flood Plan are followed and that the guidelines appropriately address District requirements for obtaining flood data in a safe and thorough manner. If deficiencies are identified, they are remedied by the Data-Section Chief, Tuscaloosa Data Unit Chief, and Surface-Water Specialist.

\section{Low-Flow Conditions}

Streamflow conditions encountered by District personnel during periods of low flow are typically quite different from those encountered during periods of medium and high flow. Lowflow discharge measurements are made to define or confirm the lower portions of stage-discharge relations for gaging stations, as part of seepage runs to identify channel gains or losses, and to help in the interpretation of other associated data. Additionally, low-flow measurements are made to define the relation between low-flow characteristics in a basin and those of a nearby basin for which more data are available (OSW memorandum 85.17). 
In many situations, low flows are associated with factors that reduce the accuracy of discharge measurements. These factors include algae growth that impedes the free movement of current-meter buckets and larger percentages of the flow moving in the narrow spaces between cobbles. When natural conditions are in the range considered by the field personnel to be undependable, the cross section is physically improved for measurement by removal of debris or large cobbles, construction of dikes to reduce the amount of nonflowing water, or other such efforts (Buchanan and Somers, 1969, p. 39). The channel modification should not be performed as to affect the recorded stage at the gage, if possible. After modification of the cross section, the flow is allowed to stabilize before the discharge measurement is initiated.

District policy requires that point-of-zeroflow (PZF) measurements be made by field personnel for all low-flow wading measurements where unstable control conditions exist. PZF's should also be collected at new gaged sites as flow conditions warrant for use in the rating and shift applications. Control conditions should be noted as part of measurement requirements.

The individual responsible for ensuring that District personnel use appropriate equipment and procedures during periods of low flow is the DataSection Chief, Tuscaloosa Data Unit Chief or Surface-Water Specialist. Determination that appropriate procedures are used for data-collection activities during low-flow conditions is accomplished by reviewing of low-flow measurements and other field activities by the Senior Technician, Data-Section Chief, Tuscaloosa Data Unit Chief or Surface-Water Specialist. The Data-Section Chief, Tuscaloosa Data Unit Chief, and Surface-Water Specialist are responsible for providing answers to questions from District personnel pertaining to data collection during periods of low flow.

\section{Cold-Weather Conditions}

Surface-water activities in this District occasionally include making streamflow-discharge measurements during cold weather conditions. Cold temperatures, wind, snow, and ice can create difficulties in collecting data. These factors also can create dangers to field personnel. The highest priority in collecting streamflow data during winter periods is employee safety.

For gaging stations where the stream is subject to freezing during the winter, discharge measurements under ice cover and during periods of partial ice cover are useful for analysis and determination of flow throughout winter periods. District personnel are required to follow procedures for discharge measurements under ice cover presented in Buchanan and Somers (1969, p. 42). This same publication includes procedures for discharge measurements made by wading or discharge measurements from cableways and bridges when debris and ice are in the streamflow. District personnel also follow procedures to collect winter streamflow data as presented in Rantz and others (1982, p. 124). Additionally, guidelines on equipment for measurement of flow under ice are provided in OSW memorandum 84.05.

Presently, OSW views the preferred metering equipment for discharge measurements for slushfree conditions under ice cover to be a type AA current meter built with a Water Survey of Canada (WSC) winter-style yoke with a conventional metal-cup rotor. For conditions where slush ice is present, the OSW views the preferred metering equipment to be the WSC winter-style yoke with a polymer rotor (OSW memorandum 88.18). Although polymer rotors are not allowed (OSW memorandum 90.01) during all other conditions, the superior ability of the polymer rotor to shed slush ice and retard freezing in ice-covered streams is considered to be more important than the turbulent-flow-related inaccuracies associated with the rotor (OSW memorandum 92.04). The OSW also views the regular $\mathrm{AA}$ meters with conventional metal-bucket rotors to be acceptable for use in slush-free conditions if cutting the required larger holes through the ice is feasible (OSW memorandum 92.04).

The responsibility for ensuring the correct use of equipment and procedures for surface-water data-collection activities during periods of winter conditions is held by the Data-Section Chief or Surface-Water Specialist. This is accomplished by ensuring that appropriate equipment and procedures are used and by reviewing all field notes immediately following winter field trips, or 
reviewing field-note sheets when station records are reviewed annually.

\section{PROCESSING AND ANALYSIS OF STAGE AND STREAMFLOW DATA}

The computation of streamflow records involves the analysis of field observations and field measurements, the determination of stagedischarge relations, adjustment and application of those relations, and systematic documentation of the methods and decisions that were applied. Streamflow records are computed and published for each gaging station annually (Rantz and others, 1982, p. 544).

This section of the QA Plan includes descriptions of procedures and policies pertaining to the processing and analysis of data associated with the computation of streamflow records. The procedures followed by the Alabama District coincide with those described in Rantz and others (1982) and in Kennedy (1983).

\section{Measurement and Field Notes}

The gage-height information, discharge information, control conditions, and other field observations written by personnel onto the measurement note sheets and other field note sheets form the basis for records computation for each gaging station. Measurements and field notes that contain original data are required to be stored indefinitely (Hubbard, 1992).

Measurements and other field notes for the water year that are currently being computed are filed in the primary station folder or in the current water year measurement file drawer. Measurements and notes for previous water years are filed in the historical files. Most of the historical discharge measurements obtained prior to 1950 have been archived at the Federal Record Center in Atlanta, Georgia.

It is District policy that all discharge measurements are checked in regard to the addition of the discharges. Other portions may either be scanned or thoroughly checked. The measurements are checked by reviewing the mathematics and other items listed in Kennedy (1983, p. 7). The measurement data are entered into computer files using standard USGS software by the person that checked the measurement. Then a paper printout of that summary information is filed in the office and station field folders.

\section{Continuous Record}

Surface-water gage-height data are collected as continuous record $(60-, 30-, 15-$, or 5 -minute values) from electronic transmissions by satellite and electronic dataloggers. Streamflow records are computed by converting gage-height record to discharge record through application of stagedischarge relations. Ensuring the accuracy of gageheight record is, therefore, a necessary component of ensuring the accuracy of computed discharges. Gage-height record is assembled for the period of analysis in as complete a manner as possible. Periods of inaccurate gage-height data are identified then corrected (see the section "Datum Corrections, Gage-height Corrections, and Shifts") or deleted as appropriate and as determined by the Data-Section Chief or Tuscaloosa Data Unit Chief. Items included in the assembly of gage-height record and procedures for processing the data are discussed in Kennedy (1983, p. 6), and Rantz and others (1982, p. 560 and 587).

Field data for the field office are entered and processed at the field office. Observer records are entered into the station database and stored. Observer information is compared to recorded station data and used in analysis of the continuous record data. Periods of missing record or questionable record are replaced with data from backup recorders where available. The authority and responsibilities associated with long-term storage of surface-water data and ensuring the integrity of that historical data are discussed in the "Data-Base Management" section of this report.

\section{Records and Computation}

Computation of streamflow data for each station are normally computed each year by the field person responsible for the data collection activities at that site. A senior technician will compute the records for new employees. All records for each station are checked by other field personnel, Data-Section Chief or Tuscaloosa Data Unit Chief using a records computation checklist. Each office is responsible for setting up necessary office files for storing collected data. 


\section{Procedures for Working and Checking Records}

Procedures for ensuring the thoroughness, consistency, and accuracy of streamflow records are described in this section of the QA Plan. The goals, procedures, and policies presented in this section are grouped in association with the separate components that are included in the recordscomputation process.

\section{Gage Height}

The accuracy of surface-water discharge records depends on the accuracy of discharge measurement, the accuracy of rating definition, and the completeness and accuracy of the gage-height record (OSW memorandum 93.07). Computation of streamflow records includes ensuring the accuracy of gage-height record by comparisons of gage-height readings made by use of independent reference gages, comparison of inside and outside gages, examination of high-water marks, comparisons of the redundant recordings of peaks and troughs by use of maximum and minimum indicators, examination of data obtained at creststage gages, and confirmation or updating of gage datums by levels.

Records computation includes examination of gage-height record to determine if the record accurately represents the water level of the body of water being monitored. Additionally, it includes identifying periods of time during which inaccuracies have occurred and determining the cause for those inaccuracies. When possible and appropriate, inaccurate gage-height data are corrected. When corrections are not possible, the erroneous gage-height data are documented in writing (station analysis) and are removed from the set of data used for streamflow records computation by the Data-Section Chief, Tuscaloosa Data Unit Chief, or technician who worked the records. All data are reviewed by the Data-Section Chief, Surface-Water Specialist, Tuscaloosa Data Unit Chief, or another representative of the Data Section.

\section{Levels}

Errors in gage-height data caused by vertical changes in the gage or gage-supporting structure can be measured by running levels. Gages can be reset or gage readings can be adjusted by applying corrections based on levels (Kennedy, 1983, p. 6) and TWRI 3-A19 (Kennedy, 1990).

Procedures for computing records and completing level information for each station include (1) ensuring that the level-notes front sheet is completed for each set of levels, (2) checking level notes, (3) ensuring that the level information is listed in the historical levels summary, and (4) ensuring that information was applied appropriately as datum corrections. The individual computing the record is required to check field notes for indications that the gages were reset correctly by field personnel. The individual computing the records makes appropriate adjustments to the gage-height record by applying datum corrections.

\section{Rating}

The development of the stage-discharge relation, also called the rating, is one of the principal tasks in computing discharge record. The rating is usually the relation between gage height and discharge (simple rating). Ratings for some special sites involve additional factors such as rate of change in stage or fall in slope reach (complex ratings) (Kennedy, 1983, p. 14).

District personnel follow procedures for the development, modification, and application of ratings that are described in Kennedy (1984). District personnel also follow guidelines pertaining to rating and records computation that are presented in Kennedy (1983, p. 14) and in Rantz and others (1982, chap. 10-14 and p. 549).

For each gaging station, the most recent digital rating table can be obtained by retrieving the rating from the District computer database or a paper copy from the current files for each station. A graphical plot of the most recent rating can be obtained from the current rating file drawers in the District office, field office file, or by using the standard USGS database software for simple ratings.

The Data-Section Chief, Tuscaloosa Data Unit Chief, or Surface-Water Specialist check and review each rating as part of the annual station analysis to ensure accuracy in the development, documentation, and application of each rating. Standard procedures as described in TWRI 3-A8, 
and TWRI 3-A10 (Kennedy, 1984, 1990) pertaining to rating development and applications are followed in data computations. All measurements are plotted on the current rating plot as standard procedure for data analysis. When personnel have questions pertaining to ratings, the Data-Section Chief, Tuscaloosa Data Unit Chief or Surface-Water Specialist is responsible for providing answers. It is District policy that new ratings are checked before copies of the ratings are sent outside the office.

\section{Datum Corrections, Gage-Height Corrections, and Shifts}

A correction applied to gage-height readings to compensate for the effect of settlement or uplift of the gage is usually measured by levels and is called a "datum correction" (Kennedy, 1983, p. 9). Datum corrections are applied to gage-height record in terms of magnitude (in feet) and in terms of when the datum change occurred. In the absence of any evidence indicating exactly when the change occurred, the change is assumed to have occurred gradually from the time the previous levels were run, and the correction is prorated with time (Rantz and others, 1982, p. 545). Datum corrections are applied when the magnitude of the vertical change is equal to or greater than 0.02 foot.

A correction applied to gage-height readings to compensate for differences between the recording gage and the base (reference) gage is called a "gage-height correction" (Rantz and others, 1982, p. 563). These corrections are applied in the same manner as datum corrections by use of the same computer software. Gage-height corrections are applied so the recorded data are made to agree with reference gage data. These corrections are applied when the difference between the recording gage and the base gage is equal to or greater than 0.02 foot.

A correction applied to the stage-discharge relation or rating to compensate for variations in the rating is called a shift. Shifts reflect the fact that stage-discharge relations are not permanent but vary with time, either gradually or abruptly, because of changes in the physical features that form the control at the gaging station (Rantz and others, 1982, p. 344). Shifts can be applied to vary in magnitude with time and with stage (Kennedy,
1983, p. 35). Most shifts are applied as variablestage adjustments in the District database applications software. Generally shifts are applied if the discharge measurements are more than 5 percent from the current rating. Although, there are factors that can affect when and how the application is determined, such as stream conditions under which the measurement was made. Judgement and experience of field personnel are used in shift applications.

During low-flow conditions shifts may be applied for periods which measurements plot less than 5 percent when several measurements define a shift curve for the lower portion of the rating. Rating development, application, and documentation are checked and reviewed by the Data-Section Chief, Tuscaloosa Data Unit Chief or Surface-Water Specialist. Review of each shift application by the Data-Section Chief, Tuscaloosa Data Unit Chief or Surface-Water Specialist ensure that stage shifts perform as expected.

Datum corrections, gage-height corrections, ratings, and shifts applications are documented as part of the annual station analysis process following the above guidelines. Paper copies of calculations, notes, and diagrams are maintained with each station analysis. Personnel may use either ADAPS generated output or hand drawn diagrams for the shift analysis. Each station record is checked to ensure proper transitions from one water year to the next.

\section{Hydrographs}

A discharge hydrograph is a plot of daily mean discharge versus time. The date is aligned with the horizontal axis and the discharge is aligned with the logarithmic vertical axis. In the process of computing station records, the hydrograph is a useful tool in identifying periods of erroneous information, such as incorrect shifts or datum corrections. Additionally, hydrographs are helpful when estimating discharges for periods of undefined stage-discharge relation, such as during backwater or ice conditions, and in estimating discharges for periods of missing record.

Information placed on the hydrograph for each station includes as a minimum station name, station number, water year, date the hydrograph 
was plotted, drainage area, plot of daily mean discharge data, plots of measurements, and also may include indications of datum corrections and shifts, streamflow stations with which the hydrograph was compared, or other. Each hydrograph is checked as part of the annual station analysis process.

Hydrograph comparisons assist the District personnel in identifying potential problems that may have been overlooked in the normal computation procedures (Rantz and others, 1982). The hydrograph is used in downstream analysis of stations on the same or adjacent basin as a tool for ensuring the quality of computed discharge record. The hydrographs are filed in the station folder during the computation process and are stored in the historical station file when computations for the water year are completed. The Data-Section Chief, Tuscaloosa Data Unit Chief or Surface-Water Specialist provide guidance when there are questions concerning hydrographs.

\section{Station Analysis}

A complete analysis of data collected, procedures used in processing the data, and the logic upon which the computations were based is documented for each year of record for each station to provide a basis for review and to serve as a reference in case questions arise about the records at some future date (Rantz and others, 1982, p. 580). Topics discussed in detail in the station analysis include location, equipment, hydrologic conditions, gage-height record, datum and gageheight corrections, rating, discharge, special computations, remarks, and recommendations as discussed by Rantz and others (1982, p. 582) and Kennedy (1983, p. 46). The station analysis is written by field personnel responsible for the data collection operations of the station during the year. New employees write station analysis with the assistance of more experienced personnel.

The Alabama District has specific forms (Appendix B) to be used in computing, checking and reviewing data included in the station analysis. The forms are obtained from the Data-Section Chief. The Data-Section Chief, his designate, or Surface-Water Specialist perform checks and final reviews of each station and places in the historical files after completion. Each person performing station analysis are required to include a consistent content for station analysis, ensure that the checker can readily obtain and check the document, and ensure that the document is properly stored for future reference even during periods of procedural and computer-equipment transitions. All pertinent streamflow data, such as station analyses, computer printouts of shifts and datum corrections, graphs of variable-shift diagrams, and hydrographs, are placed in individual permanent station file folders for archival. The Data-Section Chief is responsible for ensuring that station analyses are prepared and stored properly.

\section{Winter Records}

The Alabama District rarely has ice-affected streamflow data. However, on those few occasions, the formation of ice in stream channels or on section controls affects the stage-discharge relation by causing backwater; the effect varies with the quantity and nature of the ice, as well as with the discharge (Rantz and others, 1982, p. 360). During some conditions, the recorded gage-height data may be accurate, although the actual stagedischarge relation may be undeterminable and unstable. An example of this condition would be when surface ice forms on the stream, but the stilling well remains unfrozen and the water level in the stilling well represents the backwater caused by the ice in the channel. During other conditions, the recorded gage-height data are inaccurate, resulting in periods of missing gage-height record. An example of the latter would be when a stilling well or the intakes to the stilling well are frozen.

The individual computing the station record is responsible for identifying ice-affected periods and estimating the daily discharges during the iceaffected period. The same procedures are followed as described in the previous section under gageheight corrections.

\section{Furnished Records}

Surface-water data collected under the supervision of other agencies, organizations, or institutions are received by the Alabama District office. When received, these data are used in the annual data report publication and may be used in comparison of computed streamflow data for specific stations. If furnished data by other 
organizations, agencies, or institutions are received by the District, the data are checked and compared with other station data, if possible. The DataSection Chief, Tuscaloosa Data Unit Chief, Surface-Water Specialist, and Senior Technician are responsible for checking the data and assure that the data are in conformance with WRD standards. If errors in the data are suspected, the furnishing agency is contacted to determine if an error has been made. The Data-Section Chief, Surface-Water Specialist, Tuscaloosa Data Unit Chief, or Senior Technician is responsible for contacting the furnishing agency. Data published from another agency are not normally retained as permanent record in the District data base.

\section{Daily Values Table}

With few exceptions, for each gaging station operated by the WRD a discharge value is determined and stored for each day. The daily values table generated by use of the recordscomputation software represents what discharge values are stored for each day of the water year.

The daily values table are used during records computation to help ensure the quality of the data. The tables are used to cross check values written on primaries or plotted on the hydrograph, and to ensure that proper discharge values have been stored. The table is used to check the final manuscript before the data are published. A paper copy of the daily values table is stored for each station file folder for future reference. The Senior Technician is responsible for properly back-filing a copy after final review by the Data-Section Chief.

\section{Manuscript and Annual Report}

When records computation for the water year has been completed and the data collected and analyzed by District personnel have been determined to be correct and finalized, the surfacewater data for that water year are published along with other data in the District's annual data report. The annual data report is part of the series titled "U.S. Geological Survey Water-Data Reports." Information presented in the annual data report includes daily discharge values during the year, extremes for the year and period of record, and various statistics. Additionally, manuscript station descriptions are presented in the annual data report.
Information contained in the manuscript includes physical descriptions of the gage and basin, history of the station and data, and statements of cooperation.

In preparing the annual data report for publication, the District follows the basic guidelines presented in the report, "WRD Data Reports Preparation Guide," by Novak (1985) and OSW memorandum 92.07 (summary statistics memo). Each station is checked by someone other than the person who computed and wrote the station analysis. The final review of each station before inclusion in the annual data report is done by the Data-Section Chief, his designate, or Surface-Water Specialist. Final review of the data and publication is done by the Data-Section Chief, his designate or Surface-Water Specialist. Proof copy of the report is checked by the Data-Section Chief or Surface-Water Specialist.

\section{District Checkoff List}

Office checkoff list(s) are maintained with the current data files to track the progress of the station analysis procedures for each gaging station for each water year (Appendix B). The checkoff list is a means of tracking the status of records computation for each station and ensuring that errors do not occur by omitting the necessary procedural steps. The checkoff list is selfexplanatory and is completed by the person computing, checking and reviewing the station data. The list(s) are filed in the permanent station folder.

\section{Review of Records}

After streamflow records for each station have been computed and checked, records for all of the District's gaging stations are reviewed by the DataSection Chief, his designate, or Surface-Water Specialist. The goal of the review is to ensure that proper methods were applied throughout the process of obtaining the surface-water data and computing the record. If deficiencies are identified during the record review, the individual responsible for compiling the station analysis data are notified in writing or verbally. The individuals are responsible for correcting identified deficiencies, and to re-document the station data as necessary. If questions arise concerning the 
validity of the identified deficiencies, those questions are resolved by the Data-Section Chief or Surface-Water Specialist.

\section{Crest-Stage Gages}

Records for crest-stage gages are computed with goals and procedures similar to those for other gaging stations. The field notes are examined for correctness and accuracy. Peak stages recorded by crest-stage gages are cross referenced with other available information; the dates of the peaks are determined by analyzing available precipitation data and peak data from recording gages within the same basin or from nearby basins.

A discussion on the policies and procedures used for field aspects of collecting data at creststage gages is included in this report in the section "Collection of Stage and Streamflow Data." The discussion in this section describes the analysis and office documentation of crest-stage data. This section does not pertain to data collected at creststage gages installed solely for the purpose of confirming peak stages at sites where manometer or pressure-transducer gages are used.

At sites where crest-stage gages are used to compute peak discharges, an initial stage-discharge relation, or rating, is developed for the site by direct or indirect high-water measurements. The rating is verified or adjusted on the basis of subsequent direct or indirect high-water measurements.

For each station, a list of all measurements is maintained and each measurement is assigned a chronological number. For each station, a graphical plot and table of the current rating along with each recent and each notably high stage-discharge measurement are contained in station folder and made readily available to those who check and review the station record. These data are all stored in the District computer data base. Current station descriptions and a summary of levels are maintained in the station folders. A brief station analysis is written each year describing computation of the annual peak, identifying which rating was used and the type of flow condition, describing how the dates of the peaks were determined (Appendix B).
Responsibility for ensuring the correct computation of annual peaks at crest-stage gages is held by the Data-Section Chief or Surface-Water Specialist. Review of the crest-stage gage computations is performed by the Surface-Water Specialist and Data-Section Chief for all stations. When incorrect actions or procedures are identified during the review, the problems are corrected by the Data-Section Chief or Surface-Water Specialist.

Responsibility for updating the Peak-Flow File promptly after peak data have been finalized is held by the Surface-Water Specialist. A current listing of annual peaks is maintained in the station folder and on computer for review purposes (Office of Surface Water memorandum 88.07).

\section{OFFICE SETTING}

Maintaining surface-water data and related information in a systematic and organized manner increases the efficiency and effectiveness of dataanalysis and data-dissemination efforts. Good organization of files reduces the likelihood of misplaced information; misplaced data and field notes can lead to analyses based on inadequate information, with a possible decrease in the quality of analytical results.

This section of the QA Plan includes descriptions of how station folders, reference maps, levels documentation, and other information related to surface-water data are organized and maintained. Additionally, this section provides an overview of how work activities are designed to be carried out within the office setting.

The District and Subdistrict offices each maintain an organized file system and computer data base is available for all gaging stations in Alabama. Each office has current and historical files for each gaging station in their area. The District office has copies of all historical information on file or on computer from the field office. Other data files such as benchmarkelevation, flood-profile, and indirect-measurement are kept primarily in the District files. 


\section{Work Plan}

Routine field activities are assigned and scheduled by the Senior Technician of each office with the assistance and approval of the DataSection Chief and Tuscaloosa Data Unit Chief. Trips are run at a frequency that reflects the need to define or verify station ratings; but are conducted at a minimum frequency of every 8 weeks. Work load is based on experience and knowledge of the field personnel, but are normally distributed equally as possible. Beyond normal data-collection activities, it is very important that plans be formulated to cover extreme hydrologic events. The District Flood Plan provides basic guidance for coverage of flood events. Flood Plan implementation is supervised by the Data-Section Chief, and assisted by the Surface-Water Specialist. Low-flow events, by their very nature, have lengthy response times and appropriate personnel have ample time to plan field activities tailored to the anticipated significance of the event. Low-flow field activities for relatively minor events are directed almost exclusively by the Senior Technician for each office and with assistance by the Data-Section Chief, Tuscaloosa Data Unit Chief, or Surface-Water Specialist. Lowflow field activities for highly significant events are directed by the Data-Section Chief or Tuscaloosa Data Unit Chief with assistance from the Senior Technician with support from Section personnel.

\section{File Folders for Surface-Water Stations}

This section of the QA Plan describes the location and makeup of hard-copy files associated with surface-water data. Information pertaining to files maintained in computer storage can be found in the "Data-base Management" section of this report.

For each gaging station, a separate set of file folders are maintained for current and historical data. The current files and the historical files are organized by station number. The current files are filed in the data section filing area and the historical files are kept in the record section filing area of each office. The set of current files for each station contain primary-computation printouts, graphed data of stage and discharge, recent measurements, current rating, shift and gage-height application sheets, and other pertinent data. The set of historical file folders contains all previous water data and analyses data for the period of record and station description. Extraneous items are removed from the current files each year after records are determined by the Data-section Chief to be finalized. No historical file folders are allowed to be removed from the office. Historical file folders for the past 5 to 10 years for sites assigned to the field of fice are filed in downstream order in those offices.

\section{Field-Trip Folders}

The Alabama District maintains separate folders for each field-trip area or project study area. The primary purpose of these folders is to compile maps, station descriptions, station lists, and other pertinent information, allowing field personnel to run the trips effectively at a moment's notice and with a minimum of time spent on lastminute preparations. Each field person is responsible for maintaining current information in each of their folders.

\section{Level Notes}

Recent or current level notes are included in current file folders or are filed in the current datafile drawers. When new levels are run the old level notes are moved to the historical measurement and field-note files. The level summaries are filed in the current station-file folder. All level notes are checked for accuracy and proper leveling procedures. Any deficiencies are remedied by individual field personnel as determined by the Senior Technician or Data-Section Chief.

\section{Station Descriptions}

Surface-water station descriptions are maintained for each gaging station in the current and historical file folders. Electronic files of station descriptions are compiled and maintained on the computer system. Each field person is responsible for updating and maintaining the station description for their areas. The Senior Technician and Data-Section Chief are responsible for ensuring that folders or files are updated. 


\section{Discontinued Stations}

Discontinued station file folders are maintained in the historical files in downstream order. These station folders contain station descriptions, old analyses, old ratings, daily discharge data for each water year, and other pertinent information.

\section{Map Files}

The Alabama District office maintains three separate map file areas: drainage area maps, general topographic maps, and county maps for the State. The field office maintains two separate map file areas for topographic maps and county maps. The topographic maps and drainage area maps are organized by map number, while the county maps are organized in alphabetical order. Topographic maps are available in scales of 1:24000, and $1: 100000$; the county maps are available at various scales. The Data-Section Chief and Surface Water Specialist are responsible for updating any information on the official office maps. A set of topograghic maps is maintained by the DataSection Chief to assign downstream order numbers to stations.

\section{Archiving}

All WRD personnel are directed to safeguard all original field records containing geologic and hydrogeologic measurements and observations. Selected material not maintained in the field office are placed in archival storage. Detailed information on what records have been removed to archival centers should be retained in the District or field office (WRD memorandum 77.83). The types of original data that should be archived include, but are not limited to, recorder charts and tapes, original data and edited data, observer's notes and readings, station descriptions, analyses, and other supporting information (WRD memorandum 92.59 and Hubbard, 1992, p. 12). At this time there is an agreement between WRD and the Federal Records Centers (FRC) of the National Archives and Records Administration to archive original-data records (memorandum from the Chief, Branch of Operational Support, May 7, 1993).

Surface-water information is sent to the FRC from the Alabama District as determined by the
Data-Section Chief. The Data-Section Chief is responsible for deciding what information is sent to the FRC, for ensuring that the information is properly packed and logged, and for ascertaining that the information is received by the FRC. Records of exactly what has been archived are maintained in the surface-water section by the Data-Section Chief. Personnel who have questions concerning archiving procedures should address questions to the Data-Section Chief. Personnel who receive requests for information that require accessing archived records should contact the Data-Section Chief for assistance. All project chiefs are responsible for ensuring that appropriate project data are archived. This data includes both electronic files and hard-copy files that are associated with a particular project. Electronic data files should be archived in the top level directory "archive" on the sunldalmtg file server.

\section{Communication of New Methods and Current Procedures}

Personnel that receive training or encounter new methods or procedures are required to pass that information along to all persons directly involved in tasks that can make use of the information. Sometimes informal training is conducted by the Senior Technician, Data-Section Chief, Tuscaloosa Data Unit Chief, and SurfaceWater Specialist to pass along information to help improve the collection and analysis of streamflow data. Any new procedure is passed along to each person either in writing or verbally or both. Copies of all memorandums from WRD and OSW are given to each employee, and major points are communicated to personnel by the Senior Technician, Data-Section Chief, Tuscaloosa Data Unit Chief, and Surface-Water Specialist. Sometimes the memorandums are posted as continuous reminder to section personnel. The Senior Technician, Data-Section Chief, Tuscaloosa Data Unit Chief, and Surface-Water Specialist are available for questions and to discuss procedures.

\section{COLLECTION OF SEDIMENT DATA}

Surface-water activities in the District include the collection, analysis, and publication of sediment data. The District operates in adherence 
to policies related to sediment set forth by the OSW.

Responsibility for the sediment discipline was transferred from the Office of Water Quality (OWQ) to the OSW in 1985 (OSW memorandum 92.08). The sediment policies and procedures followed by the District are described in selected WRD publications and in memorandums issued by OSW, OWQ, and WRD. Techniques adopted by the USGS and followed by this District are presented in Knott and others (1992). The District also follows procedures described in three TWRI publications for the series Chapters:

Book 3, Chapter C1--"Fluvial Sediment Concepts" by H.P. Guy (1970),

Book 3, Chapter C2--"Field Methods for Measurement of Fluvial Sediment" by HP. Guy and V.W. Norman (1970),

Book 3, Chapter C3--"Computation of Fluvial-Sediment Discharge" by George Porterfield (1972).

Although no additional TWRI chapters have been written to supersede the above-mentioned reports, Open-File Report 86-531 "Field Methods for Measurement of Fluvial Sediment" (Edwards and G.D. Glysson, 1988) essentially replaces Book 3, Chapter C2 (WRD memorandum 71.73, OSW memorandums 88.17, and 93.01).

A summary of memorandums issued since 1971 related to sediment and sediment transport is provided in OSW memorandum 92.08. A summary of documentation that describes instrumentation and field methods for collecting sediment data is provided in OSW memorandum 93.01.

\section{Sampling Procedures}

District personnel collect suspended-sediment data by using sampling methods that include: the single vertical method, the Equal Discharge Increment (EDI) method, the Equal Width Increment (EWI) method, and the point-sample method. For installation and use of automatic pumping-type samplers, the District follows the criteria described in Edwards and Glysson (1988, p. 32).
Field methods for sediment sampling are documented in OSW memorandum 93.01. Water samples obtained for the analysis of sediment concentration and particle size are not composited (OSW memorandum 93.01 and OWQ memorandum 76.17). For samples that are split, the cone splitter is used (OWQ memorandum 80.17).

Guidelines for the collection and publication of bedload data are provided in OSW memorandum 90.08. This memorandum supersedes policy and guidelines provided in previous OWQ memorandums 76.04, 77.07, 79.17, and 80.07, as well as WRD memorandum 77.60. Among the policies stated in OSW memorandum 90.08 , which are followed by the District, is one stating that three cross-sectional procedures are used for bedload sampling: the Single Equal Width Increment (SEWI) method, the Multiple Equal Width Increment (MEWI) method, and the Unequal Width Increment (UWI) method. Additionally, it is stated in OSW memorandum 90.08 that it is the responsibility of the field personnel to select the procedure that is optimal for the local condition. Bedload samples in some situations are analyzed individually and in other situations are analyzed as a composite. Until sampling variability for a particular site is understood by those analyzing the data, all samples are required to be analyzed individually.

Responsibilities for scheduling sedimentcollection activities at specific sites are assigned to supervisor's project personnel involved in sediment related hydrologic investigations. The individual responsible for ensuring that District personnel use correct procedures to collect sediment data is the District Water Quality Specialist. This individual establishes whether or not correct procedures are being used by conducting periodic reviews of sediment field trips, sample processing, and records computation. Deficiencies are remedied through in-house training by qualified staff. Answers to questions from District personnel concerning sedimentsampling techniques are provided by the District Water Quality Specialist or by other qualified personnel who have proper training in sedimentrelated disciplines. 


\section{Field Notes}

District personnel are required to fill out note sheets each time a site is visited for the purpose of sediment sampling. The employee completes the note sheet in its entirety before leaving the site. Original observations written on the note sheets are not to be erased; data are corrected by crossing out the original observations and writing the correct information near the original value. The goal of placing information on the field note sheet is to describe the equipment and methods used during the site visit as well as to describe relevant conditions or changes (OSW memorandum 91.15). For each site visit, information included on the note sheet includes, at minimum, the site identification, field personnel name(s), date, time, sampling equipment, and method, as covered in OSW memorandum 91.15.

Upon completion of each field trip, field notes are placed in office files for future reference. Field notes are checked by data section personnel other than those who collected the sediment samples.

\section{Equipment}

Care and maintenance of the sediment-datacollection equipment is the responsibility of the field personnel who use the sampling equipment. Major parts replacement and repair of damaged equipment is accomplished through contract with the USGS Hydrologic Instrumentation Facility at Stennis Space Center in Mississippi. Minor repairs are done in-house by qualified personnel. It is the joint responsibility of the District Water Quality Specialist and project personnel to ensure that appropriate equipment is used at all sampling sites. Sampling equipment is selected based on the constituents that are being investigated, the type of analyses that are to be performed, and site conditions, including velocity and maximum depth of water. The District follows equipment-design criteria and guidelines referenced in OSW memorandum 93.01.

\section{Sample Handling and Storage}

The quality of sediment data provided by a sediment laboratory is affected by the quality of the samples received from the field (Knott and others, 1992, p. 2). District personnel are required to prepare sample labels, analysis instructions, and sample documentation according to guidelines presented in Knott and others (1992).

Sediment-sample containers and sediment samples are stored in the District and field office on-site warehouses. Samples are shipped to the Kentucky District sediment laboratory for sediment-concentration and sand-silt split analyses and to the Iowa District sediment laboratory for particle size analysis. Because sediment-sample containers are glass, they are securely taped and packed in foam-filled plastic crates for shipment to minimize the risk of breakage.

\section{High-Flow Conditions}

High-flow conditions at most streams, unless the streams are subject to the effects of backwater, are associated with high-energy conditions. The sediment flux and particle sizes associated with high flows are important factors in sediment studies conducted by the District. To ensure that field personnel are aware of their responsibilities in obtaining sediment samples at appropriate sites during high-flow conditions, a list of sedimentsampling sites and sampling requirements are provided to appropriate field personnel by the project and section chiefs involved in sediment studies. These individuals are responsible for ensuring that sediment samples are obtained during opportunities provided by high-flow events and for ensuring that the proper sampling equipment and methods are used during high-flow conditions The District Water Quality Specialist and qualified project personnel are responsible for providing answers to District personnel who have questions concerning high-flow sampling equipment or sampling procedures.

\section{Cold-Weather Conditions}

Sediment-sampling activities in this District occasionally include obtaining samples during periods of subfreezing temperatures. During coldweather conditions, field personnel should take every precaution to ensure their personal safety. Additionally, field personnel should attempt to ensure that equipment is not damaged by floating slabs of ice and that nozzles are not clogged with ice crystals. 
When floating slabs of ice pose the danger of damaging sampling equipment, such as during spring breakup, field personnel may manage only to obtain surface samples between the floating slabs of ice (Edwards and Glysson, 1988, p. 86). The procedure is noted on the field note sheet and sample label. When anchor ice and frazzle ice are present, it may be necessary to move the sampling equipment quickly through ice crystals to avoid clogging the nozzle. This procedure is also noted on the field note sheets and sample label.

\section{Site Documentation}

A station description is prepared for each new sediment-sampling site. At sampling sites where streamflow-gaging activities occur, the description of sediment activities is included in the streamflow-gaging-station description. A list of elements included in each station description, along with an explanation of what items are included with each element, is presented in the attachment to OSW memorandum 91.15. At sites where sediment samples are collected but other streamflow data are not collected, the station descriptions are structured similarly to those for streamflow-gaging stations, and contain similar informational items (Kennedy, 1983, p. 2). At sampling sites where gage houses have been installed, station descriptions are kept in the gage house for the purpose of providing field personnel with information pertinent to sediment-sampling procedures for that particular site. Station descriptions and the five most recent station analyses are included in the field folder and are maintained in the office files. Each description includes specific information explaining where the site samples are to be taken and what method is to be used. Recent station analyses contain pertinent information about the sampling conditions and problems that may have been recently encountered. As such, they are also useful field references to field crews.

The responsibility of ensuring that field copies of station descriptions and recent station analyses located at gage houses are kept current is held by field personnel assigned to regularly run specific field trips. Station descriptions are kept current by periodic review and updating by the individual that processes the sediment-station data.
Station descriptions and analyses are reviewed to ensure that they are current by the section chief or qualified project personnel. These reviews are made at least once each year. When a deficiency is identified during the review of station descriptions or analyses, the deficiency is corrected and documented by the responsible field personnel.

A log of sampling activities is kept at sampling sites in gage houses. Information recorded in this log includes the names of the individuals who conducted the sampling, dates and times of the sample collection, and the project for which the samples were collected.

\section{PROCESSING AND ANALYSIS OF SEDIMENT DATA}

Sediment and associated streamflow data are compiled to produce sediment records for specific sites. Data processing of periodic measurements consists of four steps: tabulation, evaluation, editing, and verification (OSW memorandum 91.15). The District follows the considerations and guidelines presented in Porterfield (1972), Guy (1969), and OSW memorandum 91.15 in carrying out these four steps.

The responsibility for ensuring that appropriate procedures are correctly applied in processing sediment data is jointly held by the District Water Quality Specialist and qualified project personnel. During the time the sediment data are being processed for the year by qualified personnel, field notes and work sheets for each site are maintained in appropriate office files. After the record has been completed, field notes and work sheets are maintained in office archive files.

\section{Sediment Laboratory}

A sediment laboratory is not operated in this District. Sediment samples are submitted to the USGS sediment laboratory in Kentucky according to established guidelines and procedures.

\section{Sediment Station Analysis}

A sediment station analysis is written for each sediment station operated by the District each water year. The sediment station analysis is a summary of the sediment activities at the station for a given year. The analysis describes the 
coverage of sampling, the types of samples and sampling, changes that might affect sediment transport or the record, and the methods and reasoning used to compute the record. Information included in the sediment station analysis is presented in a thorough manner, such that the checker and the reviewer can determine from the analysis the adequacy of the activities in defining the record and in accomplishing the objectives defined for the station (OSW memorandum 91.15).

Elements included in each sediment station analysis are listed in OSW memorandum 91.15 along with descriptions of the elements and examples. Station analyses are filed in appropriate office files by project personnel, and are backfiled every 5 years.

\section{Sediment Analysis Results}

Sediment concentration, sand-silt split, and particle-size data are published in the annual data report series and additionally in open-file and interpretive project reports, where appropriate.

\section{Sediment Data Storage}

Sediment data are stored both in paper files in the District Office and in computer data base files, which is part of the USGS National Water Information System (NWIS). People responsible for ensuring that the data are properly processed and maintained include the District Water Quality Specialist, project personnel, and database administrators. Paper and computer-file records are reviewed on an annual basis and any discrepancies are resolved between these personnel.

\section{DATA-BASE MANAGEMENT}

Surface-water data have been collected by personnel of the WRD and stored in computer data bases since the mid-1980's. Proper storage and maintenance of surface-water data are critical components in the effective utilization of those data. Because computer hardware and software used in the processing and storage of surface-water data are continually changing, many Districts hesitate in describing policies and procedures associated with these functions. Dealing with recurring periods of transition, in effect, emphasizes the importance of having clearly assigned authority and clearly stated procedures for correctly populating, updating, reviewing, and maintaining a data base.

All final mean daily discharge data are stored in the historical daily values files on the Alabama District computer. The Data-Section Chief is responsible for ensuring that the current (provisional) data are flagged as "final" after final reviews are made and are properly stored in the local computer data base. Various types of daily surface-water data are stored locally and nationally, and are readily accessible. Other data that may be stored include unit values, daily values, peak values, sediment, and basin characteristics. Only the Data-Section Chief, Tuscaloosa Data Unit Chief, and Surface-Water Specialist have authority to store and process finalized types of data to ensure the quality of data in the long-term or historical data files.

\section{PUBLICATION OF SURFACE-WATER DATA}

The act of Congress (Organic Act) that created the U.S. Geological Survey in 1879 established the Survey's obligation to make public the results of its investigations and research and to perform, on a continuing, systematic, and scientific basis, the investigation of the geologic structure, mineral resources and products of the National domain (U.S. Geological Survey, 1986, p. 4). Fulfilling this obligation includes the publication of surface-water data and the interpretive information derived from the analyses of surfacewater data.

\section{Publication Policy}

The USGS and WRD have created specific policies pertaining to publication of data and interpretation of those data. All WRD personnel, including those of this District, are required to abide by those policies. A brief summary of goals, procedures, and policies are presented in U.S. Geological Survey (1986, p. 4-37).

All information obtained through investigations and observations by the staff of the USGS or by its contractors must be held confidential and not be disclosed to others until the information is made available to all, impartially 
and simultaneously, through Director- or Regionalapproved formal publication or other means of public release, except to the extent that such release is mandated by law (U.S. Geological Survey, 1986, p. 14). With the approval by the Region or of the Director, hydrologic measurements resulting from observations and laboratory analyses, after they have been reviewed for accuracy by designated WRD personnel, have been excluded from the requirements to hold unpublished information confidential (U.S. Geological Survey, 1986, p. 15).

All interpretive writings in which the USGS has a proprietary interest, including abstracts, letters to the editor, and all writings that show the author's title and USGS affiliation, must be approved by the Director before release for publication. The objectives of the approved review are to final-check the technical quality of the writing and to make certain that it meets USGS publication standards and is consistent with policies of the USGS and Department of the Interior. Director or Regional report approval ensures that each publication or writing (1) is impartial and objective, (2) has conclusions that do not compromise the USGS official position, (3) does not take an unwarranted advocacy position, and (4) does not criticize or compete with other governmental agencies or the private sector (U.S Geological Survey, 1991, p. 10).

\section{Types of Publications}

Various types of publications released by the USGS are available in which surface-water data and data analyses are presented. Publications of the formal series include the Water-Supply Paper, the Professional Paper, the Bulletin, the Circular, the Techniques of Water-Resources Investigations, Special Reports, and Selected Papers in the Hydrologic Sciences (U.S. Geological Survey, 1986, p. 42). Publications in the informal series include the Water-Resources Investigations Report, the Open-File Report, and the Administrative Report (U.S. Geological Survey, 1986 , p. 52). Included in the Open-File Report series are data reports. Surface-water data collected by this District are published each year in a hydrologic data report that belongs to the annual series titled "U.S. Geological Survey Water-Data
Reports." Factors considered by the District when deciding which form of publication should be utilized in presenting various types of information are presented in Green (1991, p. 14).

\section{Review Process}

Procedures for publication and requirements for manuscript review by WRD are summarized in U.S. Geological Survey (1991, p. 36-41). This District fulfills those requirements for review and approval of reports prior to printing and distribution. All reports written by USGS personnel in connection with their official duties must be approved by the originating Division or the Director. At least two technical reviews of each report are required by WRD (U.S. Geological Survey, 1991, p. 36). Competent and thorough editorial and technical review is the most certain way to improve and assure the high quality of the final report (Moore and others, 1990, p. 24). Principles of editorial review and responsibilities of reviewers and authors are presented in Moore and others (1990, p. 24-49). Open-file reports receive an editorial review, although not mandatory, and are also reviewed for policy and reproducibility (U.S. Geological Survey, 1991, p. 36).

Several steps are taken to ensure the quality of the annual data report. The main emphasis is to ensure the quality of the original copy of manuscripts and checking the original copy, and by checking the final printed report before it is distributed. Approval of the annual data report for publication is done at the District level and distribution of the annual report via mailing lists is handled by the Data-Section Chief. The DataSection Chief is responsible for ensuring quality in the annual data report by detecting deficiencies, and by correcting those deficiencies.

\section{STREAMFLOW DATA ON THE INTERNET}

The release of real-time streamflow data to the public via the Internet has become widespread and has presented a host of new quality assurance concerns. The main concerns are the ability to present these data as "error free" and final as possible within a short or reasonable timeframe to 
the public. With the dissemination of real-time streamflow data on the Internet, WRD's responsibilities for ensuring data quality and making the public aware of its limitations has increased significantly.

One of the most critical elements in maintaining accurate real-time streamflow records is the processing of the stream-stage and discharge measurement data, rating analysis, and shift and data correction applications, as soon as practical. The Alabama District policy is that the same procedures as described earlier and used for routine streamflow data processing will be used to assure presentation of quality data on the District's web page (http://fs2daltsc.er.usgs.gov/).

The real-time streamflow data that are presented on the public web page are reviewed frequently to ensure their quality and to help prevent the distribution of erroneous data. The Alabama District uses both automated and manual review of procedures to meet this objective. The District will continue to implement procedures for addressing the presentation of quality streamflow data as new and improved methods of reviewing and screening these data become available. Assigned personnel in the Surface Water Data Section and webmaster are responsible for correcting erroneous data displayed on the web page. All data presented on the real-time web page are flagged as PROVISIONAL DATA, with an explanation on the public web page.

\section{SAFETY}

Performing work activities in a manner that ensures the safety of personnel and others is of the highest priority for the USGS and the Alabama District. Beyond the obvious negative impact unsafe conditions can have on personnel, such as accidents and personal injuries, they also can have a direct effect on the quality of surface-water data and data analysis. For example, errors may be made when an individual's attention to detail is compromised when dangerous conditions create distractions. So that personnel are aware of and follow established procedures and policies that promote all aspects of safety, the District communicates information and directives related to safety to all personnel by in-house training classes, memorandums, and videotapes. Specific policies and procedures related to safety can be found in the District Safety Plan. It is the responsibility of the Safety Officer to ensure that each employee reads and is familiar with specific safety memorandums or manuals, and attends training classes as required. Personnel who have questions or concerns pertaining to safety or who have suggestions for improving some aspects of safety should direct those questions, concerns, and suggestions to the Safety Officer.

\section{TRAINING}

Ensuring that personnel obtain knowledge of correct methods and procedures is a vital aspect of maintaining the quality of surface-water data and data analysis. By providing appropriate training to personnel, the District increases the quality of work and eliminates the source of many potential errors. Most of the training is provided for personnel by the District as "on-the-job" type training. Other types of training pertaining to data collection and analysis procedures are accomplished by in-house training by supervisors or specialists, regional training courses, or training courses through the National Training Center. The goal of training is to ensure that field and office activities are performed in accordance with specified WRD standard practices and policies, and that these activities are performed by adequately qualified, experienced, and supervised personnel.

Requests for training and career enhancement opportunities are discussed at least annually with individuals. Formal training are requested or determined by the District Training Officer. Regional and National training courses for each year are made available to each employee. Training for each employee is documented in their Career Development Plan and personnel files.

\section{SUMMARY}

Information included in this District SurfaceWater Quality-Assurance Plan documents the policies and procedures of the Alabama District that ensure high quality in the collection, processing, storage, analysis, and publication of surface-water data. Specific types of surface-water data discussed in this report include stage, 
streamflow, sediment, and basin characteristics. The roles and responsibilities of District personnel for carrying out these policies and procedures are presented, as are issues related to management of the computer data base and issues related to employee safety and training.

\section{REFERENCES}

Arcement, G.J., and Schneider, V.R., 1989, Guide for selecting Manning's roughness coefficients for natural channels and flood plains: U.S. Geological Survey Water-Supply Paper 2339, $38 \mathrm{p}$.

Barnes, H.B, 1967, Roughness characteristics of natural channels: U.S. Geological Survey Water-Supply Paper 1849, 213 p.

Benson, M.A., and Dalrymple, Tate, 1967, General field and office procedures for indirect discharge measurements: U.S. Geological Survey Techniques of Water-Resources Investigations, book 3 , chap. A1, 30 p.

Bodhaine, G.L., 1982, Measurement of peak discharge at culverts by indirect methods: U.S. Geological Survey Techniques of WaterResources Investigations, book 3, chap. A3, $60 \mathrm{p}$.

Buchanan, T.J., and Somers, WP., 1969, Discharge measurements at gaging stations: U.S. Geological Survey Techniques of WaterResources Investigations, book 3, chap. A8, $65 \mathrm{p}$.

Carter, R.W., and Davidian, Jacob, 1968, General procedures for gaging streams: U.S. Geological Survey Techniques of WaterResources Investigations, book 3, chap. A6, $13 \mathrm{p}$.

Dalrymple, Tate, and Benson, M.A., 1967, Measurement of peak discharge by the slopearea method: U.S. Geological Survey Techniques of Water-Resources Investigations, book 3, chap. A2, 12 p.

Davidian, Jacob, 1984, Computation of watersurface profiles in open channels: U.S. Geological Survey Techniques of WaterResources Investigations, book 3 , chap. A15, $48 \mathrm{p}$.
Edwards, T.K., and Glysson, G.D., 1988, Field methods for measurement of fluvial sediment: U.S. Geological Survey Open-File Report 86-531, $118 \mathrm{p}$.

Fulford, J.M., 1994, User's guide to SAC, a computer program for computing discharge by slope-area method: U.S. Geological Survey Open-File Report $\quad 94-360,31 \mathrm{p}$.

1995, User's guide to the culvert analysis program: U.S. Geological Survey Open-File Report 95-137, 35p.

Green, J.H., 1991, WRD project and report management guide: U.S. Geological Survey Open-File Report 91-224, 152 p.

Guy, HP., 1969, Laboratory theory and methods for sediment analysis: U.S. Geological Survey Techniques of Water-Resources Investigations, book 5 , chap. $\mathrm{Cl}, 58 \mathrm{p}$.

Guy, HP., 1970, Fluvial sediment concepts: U.S. Geological Survey Techniques of WaterResources Investigations, book 3, chap. C1, $55 \mathrm{p}$.

Guy, HP., and Norman, V.W., 1970, Field methods for measurement of fluvial sediment: U.S. Geological Survey Techniques of WaterResources Investigations, book 3, chap. 2, 59 p.

Hubbard, E.F., 1992, Policy recommendations for management and retention of hydrologic data of the U.S. Geological Survey: U.S. Geological Survey Open-File Report 92-56, $32 \mathrm{p}$.

Kennedy, E.J., 1983, Computation of continuous records of streamflow: U.S. Geological Survey Techniques of Water-Resources Investigations, book 3 , chap. A13, 53 p.

1984, Discharge ratings at gaging stations: U.S. Geological Survey Techniques of WaterResources Investigations, book 3, chap. A10, $59 \mathrm{p}$.

1990, Levels at streamflow gaging stations: U.S. Geological Survey Techniques of WaterResources Investigations, book 3, chap. A19, $31 \mathrm{p}$. 
Kilpatrick, F.A., and Schneider, V.R., 1983, Use of flumes in measuring discharge: U.S. Geological Survey Techniques of WaterResources Investigations, book 3, chap. A14, $46 \mathrm{p}$.

Knott, J.M., Glysson, G.D., Malo, B.A., and Schroder, L.J., 1993, Quality assurance plan for the collection and processing of sediment data by the U.S. Geological Survey, Water Resources Division: U.S. Geological Survey Open-File Report $\quad 92-499,18$ p.

Knott, J.M, Sholar, C.J., and Matthes, W.J., 1992, Quality assurance guidelines for the analysis of sediment concentration by the U.S. Geological Survey sediment laboratories: U.S. Geological Survey Open-File Report 92-33, 22 p.

Lipscomb, S.W., 1995, Quality assurance plan for discharge measurements using Broadband Acoustic Doppler Current Profilers: U.S. Geological Open-File Report 95-701, 7 p.

Matthai, HF., 1967, Measurement of peak discharge at width contractions by indirect methods: U.S. Geological Survey Techniques of Water-Resources Investigations, book 3, chap. A4, 44 p.

Moore, J.E, Aronson, D.A., Green, J.H., and Puente, Celso, 1990, Report planning, preparation, and review guide: U.S. Geological Survey Open-File Report 89-275, $81 \mathrm{p}$.

Novak, C.E., 1985, WRD data reports preparation guide, Water-Resources Investigations, book 3, chap. C3, 66 p.

Porterfield, George, 1972, Computation of fluvialsediment discharge: U.S. Geological Survey Techniques of Water-Resources Investigations, book 3, chap. C3, 66 p.

RD Instruments, 2001, Workhorse Acoustic Doppler Current Profiler Manual.
Rantz, S.E., and others, 1982, Measurements and computation of streamflow, volumes 1 and 2: U.S. Geological Survey Water-Supply Paper $2175,631 \mathrm{p}$.

Sauer, V.B., and Meyer, R.W., 1992, Determination of errors in individual discharge measurements: U.S. Geological Survey Open-File Report 92-144, 21 p.

Schroder, L.J., and Shampine, W.J., 1992, Guidelines for preparing a quality assurance plan for the district offices of the U.S. Geological Survey: U.S. Geological Survey Open-File Report 92-136, 14 p.

Shampine, W.J., Pope, L.M., and Koterba, M.T., 1992, Integrating quality assurance in project work plans of the U.S. Geological Survey: U.S. Geological Survey Open-File Report 92-162, 12 p.

Shearman, J.O., 1990, User's manual for WSPRO-A computer model for water surface profile computations: U.S. Federal Highway Administration Report, FHWA-IP-89-027, $187 \mathrm{p}$.

Smoot, GF., and Novak, C.E., 1968, Calibration and maintenance of vertical-axis type current meters: U.S. Geological Survey Techniques of Water-Resources Investigations, book 8, chap. $\mathrm{B} 2,15 \mathrm{p}$.

U.S. Geological Survey, 1986, Water Resources Division publications guide; Volume I, Publications policy and text preparation, 2d ed., revised by D.W. Alt and K.T. Iseri: U.S. Geological Survey Open-File Report 87-0205, $429 \mathrm{p}$.

U.S. Geological Survey, 1991, Suggestions to authors of the reports of the United States Geological Survey, 7th ed., revised and edited by W.R. Hansen: U.S. Geological Survey special book publication, 289 p. 
Appendixes 


\section{APPENDIX 1}

\section{Water Resources Division and Office of Surface Water Memorandums Cited}

The following memorandums were cited in this report. The memorandums are provided in their entirety in a separate report by the Office of Surface Water and are available for printing on the Office of Surface Water web page.

Office of Surface Water memorandum 02.03

Office of Surface Water memorandum 02.02

Office of Surface Water memorandum 02.01

Office of Surface Water memorandum 99.06

Office of Surface Water memorandum 97.01

Office of Surface Water memorandum 96.05

Office of Surface Water memorandum 96.04

Office of Surface Water memorandum 93.12

Office of Surface Water memorandum 93.11

Office of Surface Water memorandum 93.07

Office of Surface Water memorandum 93.01

Office of Surface Water memorandum 92.11

Office of Surface Water memorandum 92.10

Office of Surface Water memorandum 92.09

Office of Surface Water memorandum 92.08

Office of Surface Water memorandum 92.07

Office of Surface Water memorandum 92.05

Office of Surface Water memorandum 92.04

Office of Surface Water memorandum 91.15

Office of Surface Water memorandum 91.09

Office of Surface Water memorandum 90.10

Office of Surface Water memorandum 90.08

Office of Surface Water memorandum 90.01

Office of Surface Water memorandum 89.08

Office of Surface Water memorandum 89.07

Office of Surface Water memorandum 88.18

Office of Surface Water memorandum 88.17

Office of Surface Water memorandum 88.07

Office of Surface Water memorandum 87.05

Office of Surface Water memorandum 85.17

Office of Surface Water memorandum 84.05

Office of Surface Water memorandum 83.07

Water Resources Division memorandum 92.59 
Water Resources Division memorandum $\mathbf{7 7 . 8 3}$

Water Resources Division memorandum 77.60

Water Resources Division memorandum 71.73

Office of Water Quality memorandum 80.17

Office of Water Quality memorandum 80.07

Office of Water Quality memorandum 79.17

Office of Water Quality memorandum 77.07

Office of Water Quality memorandum 76.17

Office of Water Quality memorandum 76.04

Memorandum from the Chief, Branch of Operational Support, May 7, 1993. 


\section{APPENDIX 2 \\ District Forms Cited}

Forms that were cited in the manuscript are included in this appendix. 


\section{CHECKING SUMMARY}

$$
\text { Page ___ of }
$$

Water Year:

Record:

Site:

Checker:

Correction(s) to record:*

Period

Checking Remarks 


\section{ROUNDING AND MEASUREMENT PROCEDURES TO BE USED \\ BY THE ALABAMA DISTRICT FOR COMPUTATION OF DISCHARGES}

\section{Inside or Back of Measurement Sheet}

\begin{tabular}{rcc}
\multicolumn{2}{l}{ Total Discharge Measured } & Compute Partial Discharges and Areas to Nearest \\
\cline { 2 - 3 } $0-$ & 9.99 & 0.001 \\
$10-$ & 99.99 & 0.01 \\
$100-$ & 999.9 & 0.1 \\
$1000-$ & 9,999 & 1. \\
$10,000-$ & 99,999 & 10 \\
$100,000-$ & 999,999 & 100
\end{tabular}

Velocities will be used to hundredths (.01) except:

a) If most of the velocities for the measurement run below 0.50 foot per second or,

b) If the total discharge measured is less 10 cubic feet per second, then use all velocities from the meter rating table to thousandths (.001).

Front Sheet - for Area, Discharge, Velocities, Etc.

\begin{tabular}{|c|c|c|}
\hline \multicolumn{2}{|c|}{ Total Discharge or Area Measured } & Round Discharges and Areas to Nearest \\
\hline 0 & 9.99 & 0.01 \\
\hline $10-$ & 99.99 & 0.1 \\
\hline $100-$ & 999.9 & 1. \\
\hline $1000-$ & 9,999 & 10 \\
\hline $10,000-$ & 99,999 & 100 \\
\hline $100,000-$ & 999,999 & 1000 \\
\hline
\end{tabular}

Velocity - Show velocity to nearest hundredth (.01)

\section{Depths for Wading Measurements}

Depth in feet

Below 0.5

$0.5-1.5$

1.5 - Greater
Record Reading to Nearest

0.01

0.02

.05 or .10 (as conditions warrant)

\section{Depths for velocity readings}

Depth in feet

$0.3-1.5$

$1.5-2.5$

2.5 - Greater*
Meter and Depth Setting

Pygmy - .6

AA -.6

$\mathrm{AA}-.2 \& .8$

*If the .8 velocity reading is greater than the .2 velocity reading or there is a significant difference between the two velocity readings, take an additional .6 velocity reading for depths greater than 3.0 feet. 


\section{ROUNDING AND MEASUREMENT PROCEDURES TO BE USED \\ BY THE ALABAMA DISTRICT FOR COMPUTATION OF DISCHARGES--continued}

\section{Bridge and Cable Measurements}

Weight and Suspension Distance

$15 \mathrm{C}-.5 \mathrm{ft}$

$30 \mathrm{C}-.5 \mathrm{ft}$

$50 \mathrm{C}-.55 \mathrm{ft} * *$

$50 \mathrm{C}-.9 \mathrm{ft}$

$75 \mathrm{C}-1.0 \mathrm{ft}$

$100 \mathrm{C}-1.0 \mathrm{ft}$

$150 \mathrm{C}-1.0 \mathrm{ft}$
Use 2 and .8 depth method above;

and .6 depth method below depths listed

$2.5 \mathrm{ft}$

$2.5 \mathrm{ft}$

$2.75 \mathrm{ft}$

$4.5 \mathrm{ft}$

$5.0 \mathrm{ft}$

$5.0 \mathrm{ft}$

$5.0 \mathrm{ft}$

Suspension distances are from horizontal axis of current meter (through center of tailpiece and bucket wheel of AA meter) to bottom of weight.

** Meter at hole of $\mathrm{C}$ type hanger marked " 15 ". 


\section{STATION}

1. Check "Equipment" paragraph

2. Review level notes, input datum and/or gage-height corrections,

Write "Level and datum corrections" paragraph...........

3. Check gage inspections and discharge measurements, Apply corrections if necessary, Input ADAPS, Retrieve from computer . .

4. Review precipitation data, Retrieve daily value table (STAT code 6), Write precipitation record paragraph. . . . . . . . . . . .

5. Review gage-height record on primary computation sheets,

Write "Gage-height record" paragraph.

6. Rating analysis:

a. Plot discharge measurements on 'copy' of current rating curve. .

b. Compute percent departures and shifts. . . . . . . . . .

c. Enter shifts used and percent departures into measurement file. .

d. Write "Rating "paragraph, Explain shifts applied and rating used

7. Process primary computations for year, Plot hydrograph with other

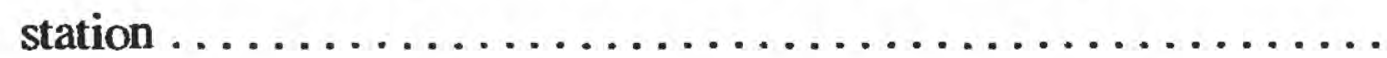

8. Compile discharge estimates for periods of missing record,

Enter in ADAPS . . . . . . . . . . . . . . . . . . . . .

9. Retrieve and check 'final' daily value table.

Compare hydrograph with other station

10. Run end of year summary (HT6), Verify peaks above base,

DO NOT SUBMIT TO PEAK FLOW FILE . . . . . . . . .

11. Run base plot

12. Write "Discharge" and "Remarks" paragraphs

13. Prepare manuscript

14. General review, Submit manuscript for typing

15. Check final manuscript $\ldots \ldots \ldots \ldots \ldots \ldots \ldots \ldots \ldots \ldots \ldots \ldots \ldots \ldots \ldots \ldots$

16. Type station analysis, Make updates or redraw rating curves......

17. Backfile data and/or place in current year folder.

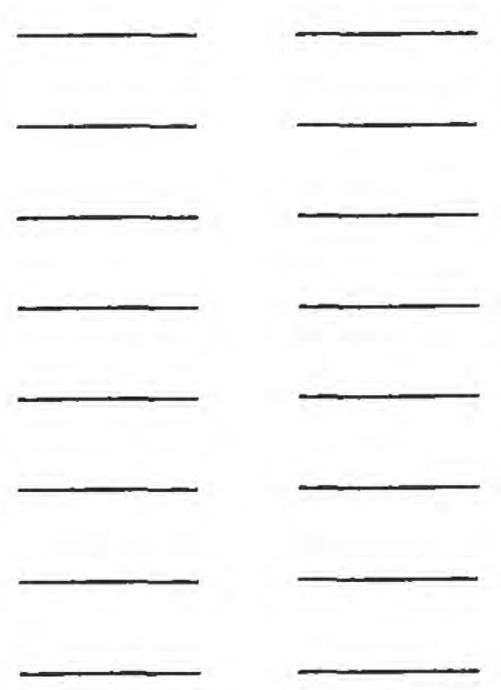




\section{List of items in station folder for review:}

Station description

9-207

Rating work curve and v-diagrams

Computer-generated shift analysis or measurement list work sheet

Computer- generated shift and datum corrections

Hydrograph and final daily value table

End-of-year analysis

Manuscript

Station analysis

Miscellaneous data (charts, observer readings, etc.)

\section{REMARKS}




\section{Field Inspection Notes}

Station No.

Station Name

Date Party

Stage at (time)

Determined by

HIGH-WATER MARKS FROM REFERENCE GAGE

\begin{tabular}{|l|l|l|l|}
\hline Gage & Distance above ref. plug & $\begin{array}{c}\text { Elevation } \\
\text { Ref. plug }\end{array}$ & $\begin{array}{c}\text { Elevation } \\
\text { Peak }\end{array}$ \\
\hline & & & \\
\hline & & & \\
\hline
\end{tabular}

Date of peak

Source

Remarks (quality of HWM, etc.)

HIGH-WATER MARKS FOR SUPPLEMENTAL GAGES

\begin{tabular}{|l|l|l|l|}
\hline Gage & Distance above ref. plug & $\begin{array}{c}\text { Elevation } \\
\text { Ref. plug }\end{array}$ & $\begin{array}{c}\text { Elevation } \\
\text { Peak }\end{array}$ \\
\hline \hline & & & \\
\hline & & & \\
\hline & & & \\
\hline
\end{tabular}

ADDITIONAL COMMENTS 